\title{
Edaphic Soil Levels of Mineral Nutrients, pH, Organic Matter, and Cationic Exchange Capacity in the Geocaulosphere Associated with Potato Common Scab
}

\author{
George Lazarovits, Jacquelyn Hill, Greg Patterson, Kenneth L. Conn, and Nigel S. Crump
}

\begin{abstract}
First, second, and fourth authors: Southern Crop Protection and Food Research Centre, Agriculture and Agri-Food Canada, 1391 Sandford Street, London, ON, N5V 4T3, Canada; third author: A\&L Canada Laboratories Inc., 2136 Jetstream Road, London, ON, N5V 3P5, Canada; and fifth author: Primary Industries Research Victoria, Department of Primary Industries, Private Bag 15, Ferntree Gully Delivery Centre, Victoria, 3156, Australia.
\end{abstract}

Accepted for publication 7 March 2007.

\begin{abstract}
Lazarovits, G., Hill, J., Patterson, G., Conn, K. L., and Crump, N. S. 2007. Edaphic soil levels of mineral nutrients, $\mathrm{pH}$, organic matter, and cationic exchange capacity in the geocaulosphere associated with potato common scab. Phytopathology 97:1071-1082.

In order to determine possible relationships between geocaulosphere soil properties and severity of common scab of potato caused by Streptomyces scabies, soils were collected from representative commercial potato fields in Canada: in Simcoe and Dufferin Counties, Ontario and across Prince Edward Island (PEI) in August 2004. Soils immediately adjacent to tubers were sampled and analyzed for select edaphic factors and for pathogen presence using polymerase chain reaction (PCR) tests with primers that amplify a region of the $T x t A$ gene involved in regulating the biosynthesis of the thaxtomin toxin family. Individual tubers were assessed visually for scab severity. The relationships between soil chemical factors and disease severity were investigated for each region to detect the strongest relationships. Principal component analysis revealed a

only factors found associated with high disease severity in soils from both provinces. In PEI soils, $\mathrm{pH}, \mathrm{Mg}, \mathrm{Ca}, \mathrm{Cu}$, and $\% \mathrm{~K}, \% \mathrm{Mg}, \% \mathrm{Ca}$, and $\% \mathrm{Na}$ were associated with high disease severity, whereas cation exchange capacity (CEC) and $\mathrm{Al}$ were correlated with low disease severity soils. In Ontario, high Mn content was strongly correlated with low disease severity soils, whereas $\% \mathrm{~K}$ and organic matter content were correlated with disease severity. Partitioning samples into presence or absence of the TxtA PCR product with corresponding high or low severity showed further significant relationships in the data. There was an excellent correlation between Streptomyces spp. presence as detected by PCR and disease severity in PEI soils; however, the relationship was not as clear in Ontario soils, where many PCR-positive soils had low disease incidence. Principal component and partial least square analysis indicated that disease severity was predicted by soil factors such as organic matter, $\mathrm{CEC}, \mathrm{pH}, \mathrm{Al}, \% \mathrm{Ca}, \% \mathrm{Mg}$, and $\% \mathrm{~K}$ for PEI but not for Ontario soils. The data reveal that the relationship between scab severity and soil chemical components is complex and potentially soil specific.
\end{abstract} distinctive clustering of samples with respect to disease severity in PEI but not in Ontario soils. Total and percent saturation of $\mathrm{K}(\% \mathrm{~K})$ were the

Common and deep-pitted scab of potato, most commonly caused by Streptomyces scabies (Thaxter) Lambert \& Loria (27), have become the limiting factors of production for some growers in Canada and elsewhere in the world. In Canada, losses to scab cost growers $\approx \$ 18$ million in 2004 (13) at a time when the industry was worth $\$ 883$ million (45).

There are no effective methods for disease control. Varying degrees of tolerance to scab exist in some cultivars but most are not commercially desirable in North America (40). The recommended cultural practices, which include management of moisture and $\mathrm{pH}$, do not always provide significant reductions in disease severity in problem fields. The impact of several cultural practices on scab incidence was monitored for 3 years by Waterer (51). Early planting resulted in lower scab incidence due to the cooler temperatures that occurred during tuber set, but also resulted in lower yields (51). Regulating moisture by irrigation at tuber set is suggested to control scab (40) but does not provide consistent results, and irrigation is not available to many producers.

Corresponding author: G. Lazarovits; E-mail address: Lazarovitsg@ agr.gc.ca

doi:10.1094/PHYTO-97-9-1071

This article is in the public domain and not copyrightable. It may be freely reprinted with customary crediting of the source. The American Phytopathological Society, 2007.
Additional keywords: multivariate analysis, potato scab, soil nutrients.
Optimization of soil $\mathrm{pH}$ to levels $<5.2$ has been proven to reduce scab incidence in many locations (40). Acid-forming fertilizers such as ammonium sulfate and ammonium phosphate also can reduce scab effectively (43). The effect of $\mathrm{pH}$, however, is possibly pathogen specific, because $S$. acidiscabies Lambert and Loria causes disease in soils as low as pH 3.8 (22). Furthermore, modifying $\mathrm{pH}$ can be a difficult problem in highly buffered soils.

A number of soil macro- and micronutrients have been implicated in modifying disease severity $(14,16,29)$. The effect of calcium following liming was related to both $\mathrm{pH}$ increases and to increased availability of calcium (22). However, the specific impact of each factor in creating conditions favoring disease has not been clearly resolved. Lacey and Wilson (20) found that scab severity was related to soil $\mathrm{pH}$ combined with the measure of exchangeable $\mathrm{Ca}, \mathrm{Mg}$, and $\mathrm{K}$ cations in Tasmanian ferrosol soils. Scab was not observed in soils when there was a combined cation exchange capacity (CEC) of $\leq 12 \mathrm{cmol}_{\mathrm{C}} / \mathrm{kg}$ of soil and $\mathrm{pH}$ levels were $<4.9$. Exchangeable Al values were reported to be negatively correlated with scab severity in soils from Hokkaido, Japan (43). The effect of Al in these soils was more closely correlated with scab severity than was $\mathrm{pH}$. However, $\mathrm{Al}$ content of soils is highly $\mathrm{pH}$ dependent. Similarly, Mn availability, which also is highly $\mathrm{pH}$ dependent, has been implicated in reducing scab severity (22). Applications of $\mathrm{MnSO}_{4}$ were found to reduce scab in four Mndeficient soils in Scotland (32). 
Nitrogenous amendments applied to scab-infested soils were shown to reduce scab levels at harvest in some soils, but not all $(5,23,24)$. Liquid swine manure was effective in acid soils where the active ingredients, shown to be volatile fatty acids, were present at sufficient concentration to impact pathogen populations (24). With many of the amendments, organic matter (OM) content and buffering capacities were the major factors influencing efficacy (24). We have seen much higher scab severity in plots deficient in nitrogen $(\mathrm{N})$ than those provided appropriate rates of $\mathrm{N}$ fertilizer (G. Lazarovits, personal observation). Keinath and Loria (19) suggested that it is the acidification of the soil following nitrification of ammonium that is the primary mechanism for reducing scab infection.

Scab severity can vary widely across fields, suggesting that physical and chemical factors may play an important role in the establishment of this pathogen. What these factors are, however, still needs to be clarified. Multivariate analysis of soil mineral nutrient levels with respect to scab disease severity could help to resolve the most important relationships that affect pathogen establishment and growth and, subsequently, tuber health. Many of these factors are collinear and influence multiple factors, although some may be more influential than others. Principal components analysis (PCA) is an extremely useful data reduction method that allows for the identification of correlations among variables that most strongly contribute to the overall data variance $(3,41)$. Once the significant variables are identified, their role in disease induction then can be studied in more detail. This statistical method has been used extensively in agriculture to study numerous factors relating productivity and management practices (10), susceptibility of apple cultivars to apple scab (8), soil receptivity to plant pathogens (36), and the effect of soil and topographic properties on crop yield (46). This statistical tool is used widely in soil ecology studies to identify factors with respect to various biological systems $(7,21,28,35,46)$.

Partial least squares (PLS) regression is another multivariate method that can be used to study the complement of soil-specific variables that predispose plants to disease when the pathogen is present in the soil. This method explains predictor variation as for PCA, but it also focuses equally on response variation and the covarying relationship between the two (9). It has been used to reveal relationships in soil with respect to cotton yield and quality (39) and to identify soil fertility factors that are most predictive of ryegrass yield (46). Recent publications used PLS analysis to determine how spectral reflectance data can be best used to assess various types of agricultural research $(4,17,33)$.

In general, the literature on the influence of soil chemical factors on scab severity is inconclusive at best, except for the influence of $\mathrm{pH}$. In a literature review on the impact of 10 plant nutrients on potato scab, Keinath and Loria (19) observed that some of the confusion associated with conflicting affects of a specific soil component could be resolved by examining interactions on the tuber surface between edaphic factors and disease intensity. Some of the confusion also could be resolved by using statistical analysis more appropriate for the complex interactions occurring there rather than looking at what may be happening in the bulk soil (19). In a previous study, we reported that, in fact, the largest differences in bacterial populations with respect to pathogenicity occurred in soils adjacent to the seed piece or the developing tubers and that the bacteria populations at some distance from these sites was relatively homogeneous (50). Therefore, the objective of this study was to examine the relationships between scab severity; edaphic factors such as $\mathrm{pH}$, OM content, and mineral nutrient levels; and the presence of pathogen as determined by polymerase chain reaction (PCR) in soils collected from the tuber surface (geocauloshpere) at numerous sites in two provinces of Canada with distinct soil characteristics. Inherent to this objective is the development of a parsimonious model by the use of predictive modeling that retains the mini- mum explanatory variables in order to simplify these complex relationships.

\section{MATERIALS AND METHODS}

Sampling of soils and tubers. In 2002, soil and tubers were sampled from 69 growers' fields of 8 to 40 ha in size in Simcoe and Dufferin Counties, Ontario, in mid-August to early September. Simcoe and Dufferin Counties are two of the major potatoproducing areas in Ontario. Agronomists were asked to guide us to fields that had scab ratings from previous crops ranging from 0 to severe. They did not tell us the scab severity of the field at the time sampling occurred. At each field, one sampling location was chosen and tubers and soil were collected from five plants (cv. Snowden). Soil adjacent to each of the five plants was removed from the hill and pooled into one bulk sample for all five plants. The bulked soils for each location were air dried and stored at $4^{\circ} \mathrm{C}$ for no longer than 3 months before analysis for soil chemical and physical properties and $\mathrm{pH}$ determination. Samples were analyzed for soil nutrients as described below. The amount of scab coverage was determined for all of the tubers based on a 0 to- 6 scale that evaluated the percentage of lesion coverage on the tuber surface, where $0=$ no disease, $1=$ trace to $5 \%, 2=6$ to $15 \%, 3=16$ to $25 \%, 4=26$ to $35 \%, 5=36$ to $60 \%$, and $6=61$ to $100 \%$. A simple mean scab index then was assigned to each sampling location (five plants).

In 2004, soil and tubers were sampled from 14 growers' fields of 8 to 40 ha in size in Simcoe and Dufferin Counties, Ontario and 10 fields across Prince Edward Island (PEI) in mid-August to early September. As in 2002, agronomists were asked to guide us to fields that had scab ratings from previous crops ranging from 0 to severe. They did not tell us the scab severity of the field at the time sampling occurred. Either three or five sampling locations were chosen from representative areas within each field. Tubers and soil were collected from five plants (cv. Snowden) at each sampling location. Soil immediately adjacent to all daughter tubers (tuber geocaulosphere) of a plant was carefully removed from the hill using an inverted plastic bag. The bulked soils for each plant were stored as described above. Samples were analyzed for soil nutrients as described below. The amount of scab coverage was determined for all the tubers attached to each plant as described above. A simple mean scab index then was assigned to each plant tuber sample.

Soil nutrient analysis. The levels of soil nutrients determined for each site, conditions for analysis, and respective methods of analysis are listed in Table 1. All analyses were carried out by A\&L Canada Laboratories Inc. (London, ON, Canada).

PCR. Soil $(\approx 2 \mathrm{~g})$ was further air dried for $\approx 2$ days at room temperature before extracting DNA from $0.5 \mathrm{~g}$ by use of a soil DNA extraction kit (Ultra Clean Soil DNA kit, MoBio Laboratories Inc., Solana Beach, CA). Kit protocols were followed with the following modifications: (i) a bead beater was used in the first step (Fast Prep FP120 by Bio 101, setting 5.5 for 30 s), (ii) solution S4 used for washing DNA immobilized on a spin-tube filter was used twice instead of once, and (iii) template DNA was suspended in $50 \mu \mathrm{l}$ of solution S5. Template DNA was amplified in a PCR reaction with primers for the TxtA gene (49). A positive result with these primers demonstrates the pathogenicity potential of the soil sample because these primers were correlated with pathogenic Streptomyces spp. colonies (50). Template DNA derived from type strains of $S$. turgidiscabies and $S$. acidiscabies (ATCC 49003) (cultures provided by C. Goyer, Agriculture and Agri-Food Canada, Fredericton, New Brunswick, Canada) also tested positive for these primers.

Statistical analysis. Analyses were performed with the Statistical Analysis System (SAS) program for Windows (version 9.1; SAS Institute, Cary, NC), Minitab (release 13.3; State College, PA), the Unscrambler program (version 9.5; CAMO, Process AS, 
Oslo, Norway), and the RPART (2) algorithm implemented in S Plus for Windows (version 6.1; Insightful Corp., Seattle, WA). Spearman rank correlations between scab index and each of the soil physical properties were determined using the CORR procedure in SAS. The scab index was dichotomized for some analyses to represent the degree of scab acceptable for processing potato ( $\leq 5 \%$ tuber coverage). A majority of the variables were not normally distributed even after various transformations; therefore, median differences were tested by the Wilcoxon rank-sum test. Prior knowledge of soil nutrient categorizations with respect to the effect on disease for specific variables (CEC, percent saturation of $\mathrm{K}[\% \mathrm{~K}], \% \mathrm{Mg}, \% \mathrm{Ca}, \% \mathrm{P}$, and $\mathrm{K}: \mathrm{Mg}$ ratio) was used to test whether these categorized variables were associated with scab severity in these data by the Wilcoxon rank-sum test or KruskalWallis test. Other continuous variable nutrients that were significantly different between diseased and nondiseased plants were dichotomized by the method of recursive partitioning (48) using the RPART algorithm (2). The variable cut-point that optimally split the sample into subgroups as homogeneous as possible of scabby compared with scab-free tubers was chosen by the algorithm (48).

For determination of specific relationships between soil factors and the presence of thaxtomin PCR amplicon in a soil sample, the disease severity data from individual plants were used rather than the means of five plants, because soil from some plants within a site could be either Txt negative or positive by PCR.

PCA is a statistical technique that, in this case, identified combinations of significant properties measured from various soil samples. Other variables, such as the physical properties of moisture and soil compaction, as well as biological and cultural factors, were not measured for this analysis. The number of multivariate measurements was reduced to linear combinations (principal components) summarizing the contribution of each variable (42). Each principal component has variance associated with the data. The values of the second principal component are not correlated with the values of the first principal component; thus the variability each soil property contributes can be represented in a two-dimensional space. Variables with larger coefficients in each principal component indicate an important role of that variable with respect to each component (35).

The output of PCA includes variable loadings for each component and scores for each sample in a component. The position of a sample score on a two-dimensional principal component plot may be directly related to variable characteristics of that sample as shown by the variable loading.

The PLS regression method (31) was performed using the Unscrambler program. The data used for analysis were the mean values of five plants from each sample location in a field. Hence, each field was represented by three replicates in most cases. Each variable was weighted prior to analysis to ensure that variables with large absolute measures or large variance were not disproportionately represented in the analysis. The models were derived by full cross-validation during each run. All independent variables were included in the first model calculated. Significant variables determined by the Martens' Uncertainty test (30) were next used to calculate more parsimonious models using full cross-validation. The root mean square error for prediction (RMSEP) and calibration (RMSEC) were examined, as well as the correlation coefficient between actual and predicted response, and percent variance explained by the model to aid in judging the goodness of fit. Residual diagnostics were used to confirm that no single observation or variable was influential in the final model.

\section{RESULTS}

Variability of soil chemistry and scab severity. Soils from Ontario generally are classified as a sandy loam and are made up of $\approx 70 \%$ sand, $23 \%$ silt, and $6 \%$ clay. PEI soils generally are composed of $60 \%$ sand, $23 \%$ silt, and $16 \%$ clay. The mean and percent coefficient of variance $(\% \mathrm{CV})$ for each of the continuous variables from each location sampled in 2002 and 2004 are shown in Table 2. Soil factors measured from bulk soil (2002 sampling) generally had higher \%CV values than soil factors measured from the geocaulosphere (2004 sampling). Samples from Ontario in 2004, on average, had less scab than those from PEI (Table 2). The means of most variables were significantly different between the two 2004 locations and, thus, were analyzed separately with respect to scab prevalence. The most obvious differences between the Ontario and PEI soils were in the mean $\mathrm{pH}, \mathrm{CEC}, \mathrm{OM}, \mathrm{K}$, $\mathrm{Mg}, \mathrm{Ca}, \% \mathrm{Mg}, \% \mathrm{Ca}, \mathrm{Mn}, \mathrm{Al}$, and the $\mathrm{K}: \mathrm{Mg}$ ratio (Table 2). Also, increasing scab severity was significantly associated with a positive PCR TxtA reaction in only PEI geocaulosphere soil samples, in contrast to those from Ontario (Table 3). Therefore, it was necessary to analyze the data separately.

Correlation of soil chemistry and scab severity. Spearman correlations of soil properties and disease severity for Ontario and PEI are shown in Tables 4 and 5, respectively. No factors were significantly correlated with scab severity when bulk soil was sampled in Ontario fields in 2002 (Table 4). In 2004, when soil was sampled from the geocaulosphere, a number of correlations were observed. In Ontario soils but not PEI soils, the OM content was found to be significantly positively correlated with scab index (Tables 4 and 5).The percent base saturation of $\mathrm{K}$ was another factor positively correlated with scab severity among Ontario fields (Table 4). Disease severity, however, was negatively correlated with Mn concentration in Ontario soils but, in PEI soils,

TABLE 1. Soil properties studied and procedures followed for measurement ${ }^{\mathrm{x}}$

\begin{tabular}{lll}
\hline Variable (units) $^{\mathrm{y}}$ & Abbreviation & Method $^{\mathrm{z}}$ \\
\hline Cation exchange capacity (meq/100 g of soil) & $\mathrm{CEC}$ & Ammonium displacement \\
Organic matter (LOI\%) & $\mathrm{OM}$ & Loss on ignition \\
Phosphorous (ppm) & $\mathrm{P}$ & Weak Bray method \\
Potassium (ppm) & $\mathrm{K}$ & Ammonium acetate extractable \\
Magnesium (ppm) & $\mathrm{Mg}$ & Ammonium acetate extractable \\
Calcium (ppm) & $\mathrm{Ca}$ & Ammonium acetate extractable \\
Sodium (ppm) & $\mathrm{Na}$ & Ammonium acetate extractable \\
Zinc (ppm) & $\mathrm{Zn}$ & Mehlich 3-extractable \\
Manganese (ppm) & $\mathrm{Mn}$ & Mehlich 3-extractable \\
Copper (ppm) & $\mathrm{Cu}$ & Mehlich 3-extractable \\
Exchangeable aluminum (ppm) & $\mathrm{Al}$ & KCl extraction \\
Nitrate (ppm) & $\mathrm{NO}$ & $\ldots$ \\
Percent saturation of P & $\% \mathrm{P}$ & $\ldots$ \\
Percent base saturation of K, Mg, Ca, Na & $\% \mathrm{~K}, \mathrm{Mg}, \mathrm{Ca}, \mathrm{Na}$ & $\ldots$ \\
Ratio of $\% \mathrm{~K}$ to $\% \mathrm{Mg}$ & $\mathrm{K}: \mathrm{Mg}$ & $\ldots$ \\
\hline
\end{tabular}

${ }^{\mathrm{x}}$ Other properties were measured but had negligible impact on scab for these data.

y Dried soil was the starting material for all procedures listed.

${ }^{z}$ Methods from Gavlak et al. (11) or Jones (18). 
no relationship was found between $\mathrm{Mn}$ and disease severity (Tables 4 and 5). In PEI soils, highly significant correlations were found between scab and soil $\mathrm{pH}, \mathrm{Cu}$, and percent base saturation of $\mathrm{K}, \mathrm{Na}, \mathrm{Ca}$, and $\mathrm{Mg}$. In contrast, $\mathrm{CEC}$ and $\mathrm{Al}$ were strongly negatively correlated with scab severity (Table 5). The only common factor associated with disease severity in soils from both provinces was \% $\mathrm{K}$ (Tables 4 and 5).

Comparison of the means of the various chemical components from Ontario and PEI fields and their relationships to disease severity in low (index $\leq 1$ ) and higher (index $>1$ ) severity soils are shown in Table 6. Ontario soils with higher disease incidence had significantly $(P<0.05)$ higher $\mathrm{K}$ and $\% \mathrm{~K}$ than those with lower disease. Ontario soils with lower disease had significantly higher $\mathrm{Mn}$ and $\mathrm{Cu}$ than those with high disease (Table 6). PEI soils with higher scab severity had significantly higher $\mathrm{pH}, \% \mathrm{~K}, \% \mathrm{Mg}$, $\% \mathrm{Ca}, \% \mathrm{Na}$, and $\mathrm{Cu}$ than soils with low scab severity (Table 6). Interestingly, $\mathrm{pH}$ was not a significant factor in Ontario soils because it was identical at 7.3 for soils with both high and low scab severities (Table 6). PEI soils with low scab incidence had significantly higher levels of CEC and Al than those with higher levels of scab. No differences in scab severity and Mn levels was observed in PEI soils because Mn in these samples were one-half to one-third that found in Ontario soils (Table 6). As previously mentioned, the only common factor found in soils from both provinces that differed significantly between geocaulosphere soil samples when comparing high and low scab severity was $\% \mathrm{~K}$; soils with more severe scab had higher $\% \mathrm{~K}$ than those with low severity in both Ontario and PEI.

Relationship between soil chemistry and scab severity. Because different factors, some collinear, were significantly associated with scab in different regional locations and soil types, a multivariate analysis was used to examine all the interacting rela-

TABLE 2. Distribution of soil properties for Ontario and Prince Edward Island (PEI) soils

\begin{tabular}{|c|c|c|c|c|c|c|}
\hline \multirow[b]{2}{*}{ Variable } & \multicolumn{2}{|c|}{ Ontario $(2002)^{\mathrm{v}}$} & \multicolumn{2}{|c|}{ Ontario $(2004)^{\mathrm{w}}$} & \multicolumn{2}{|c|}{ PEI $(2004)^{x}$} \\
\hline & Mean & $\% \mathrm{CV}^{\mathrm{y}}$ & Mean & $\% \mathrm{CV}$ & Mean & $\% \mathrm{CV}$ \\
\hline Scab inde $x^{z}$ & 1.4 & 81 & 0.7 & 102 & 2.4 & 61 \\
\hline $\mathrm{pH}$ & 6.9 & 12 & 7.3 & 3 & 5.8 & 3 \\
\hline CEC & 10.9 & 34 & 13 & 8 & 8.6 & 9 \\
\hline $\mathrm{OM}$ & 2.7 & 57 & 4.0 & 10 & 2.9 & 11 \\
\hline $\mathrm{P}$ & 240 & 44 & 130 & 18 & 160 & 14 \\
\hline K & 220 & 38 & 300 & 18 & 220 & 15 \\
\hline $\mathrm{Mg}$ & 160 & 51 & 270 & 9 & 68 & 12 \\
\hline $\mathrm{Ca}$ & 1,470 & 56 & 1,800 & 7 & 640 & 11 \\
\hline $\mathrm{Na}$ & 11 & 145 & 10 & 37 & 12 & 20 \\
\hline$\% \mathrm{~K}$ & 5.5 & 38 & 6.2 & 18 & 7.1 & 18 \\
\hline$\% \mathrm{Mg}$ & 12.4 & 40 & 18 & 25 & 6.8 & 14 \\
\hline$\% \mathrm{Ca}$ & 6.4 & 29 & 69 & 5 & 40 & 14 \\
\hline$\% \mathrm{Na}$ & 0.5 & 97 & 0.4 & 37 & 0.6 & 21 \\
\hline$\% \mathrm{P}$ & 25 & 47 & 15 & 18 & 14 & 13 \\
\hline $\mathrm{Zn}$ & 12.2 & 58 & 10.0 & 25 & 2.5 & 12 \\
\hline $\mathrm{Mn}$ & 50 & 41 & 65 & 6 & 28 & 10 \\
\hline $\mathrm{Cu}$ & 2.5 & 79 & 2.3 & 16 & 1.8 & 10 \\
\hline $\mathrm{Al}$ & 1,020 & 21 & 1,100 & 3 & 1500 & 4 \\
\hline $\mathrm{NO}_{3}$ & 39 & 39 & 25 & 12 & 25 & 13 \\
\hline $\mathrm{K}: \mathrm{Mg}$ & 0.5 & 37 & 0.4 & 16 & 1.1 & 14 \\
\hline
\end{tabular}

${ }^{v}$ Soil from 69 fields. Five samples were collected per field adjacent to the plants and pooled into one sample $(n=69)$.

${ }^{\text {w }}$ Soil from 14 fields and five locations (fields 6, 13, and 14) or three locations (all the rest of the fields) per field. Data from the five geocaulosphere soil samples per location were averaged for this comparison $(n=48)$.

${ }^{x}$ Soil from 10 fields and three locations per field. Data from the five geocaulosphere soil samples per location were averaged for this comparison $(n=30)$.

y Percent coefficient of variance $(\% \mathrm{CV})$ over the five sampled plants.

${ }^{\mathrm{z}}$ Scale of 0 to 6 based on percent tuber surface area coverage, where $0=$ no disease, $1=$ trace to $5 \%, 2=6$ to $15 \%, 3=16$ to $25 \%, 4=26$ to $35 \%, 5=36$ to $60 \%$, and $6=61$ to $100 \%$. Note: all variables were significantly different $(P<0.025)$ between locations in 2004 except $\mathrm{S}, \% \mathrm{P}, \mathrm{P}, \mathrm{Na}, \% \mathrm{~K}, \mathrm{Fe}, \mathrm{Cu}$, and $\mathrm{NO}_{3}$. tionships of the soil variables and to decide which factors were the most influential in the development of scab. Multivariate analyses were performed separately with data from both locations because each location had a distinct set of variables influencing the development of scab. PCA of the soil chemistry relationships among soils collected from Ontario resulted in $78.6 \%$ of the total variation explained in the first five principal components. When the variable loadings of the first two principal components were plotted for Ontario soils (46\% of the total variability), a positive relationship was found among the variables $\mathrm{pH}, \mathrm{CEC}, \mathrm{Mn}, \mathrm{Ca}$, and $\% \mathrm{Ca}$, and a negative correlation with $\mathrm{Al}$ was evident (Fig. 1A). A bivariate correlation with $\mathrm{pH}$ for $\mathrm{CEC}, \mathrm{Mn}, \mathrm{Al}$, and $\% \mathrm{Ca}$ also was found in results shown in Table 4. In Ontario soils, phosphorous ( $\mathrm{P}$ and \% $\mathrm{P}$ ) variables were positively correlated with $\mathrm{K}, \% \mathrm{~K}, \mathrm{Zn}$, and $\mathrm{K}: \mathrm{Mg}$ variables and negatively correlated with $\mathrm{Mg}, \% \mathrm{Mg}, \mathrm{NO}_{3}$, and $\mathrm{OM}$ in both components (Fig. 1A).

Results of relationships from PCA among chemical components of soils from PEI (Fig. 1B) showed some similarities. In all, $86 \%$ of the total variation was represented by five principal

TABLE 3. Frequency of $T x t A$ reactivity in geocaulosphere soil samples compared with severity of scab on tubers in Ontario and Prince Edward Island soils

\begin{tabular}{|c|c|c|c|c|c|c|}
\hline \multirow[b]{4}{*}{ TxtA reactivity } & \multicolumn{6}{|c|}{ Number of geocaulosphere soil samples } \\
\hline & \multicolumn{3}{|c|}{ Ontario $^{x}$} & \multicolumn{3}{|c|}{ Prince Edward Island ${ }^{y}$} \\
\hline & \multicolumn{2}{|c|}{ Scab index ${ }^{z}$} & \multirow[b]{2}{*}{ Total } & \multicolumn{2}{|c|}{ Scab index ${ }^{z}$} & \multirow[b]{2}{*}{ Tota } \\
\hline & $>1$ & $\leq 1$ & & $>1$ & $\leq 1$ & \\
\hline+ & 40 & 161 & 201 & 102 & 8 & 110 \\
\hline - & 4 & 31 & 35 & 0 & 36 & 36 \\
\hline Total & 44 & 192 & 236 & 102 & 44 & 146 \\
\hline
\end{tabular}

${ }^{x}$ Soil from 14 fields in 2004, five locations (fields 6, 13, and 14) or three locations (all the rest of the fields) per field, and five geocaulosphere soil samples per location $\left(n=236\right.$, four soil samples missing); $\chi^{2}=1.41, P>$ 0.05 .

${ }^{y}$ Soil from 10 fields in 2004, three locations per field, and five geocaulosphere soil samples per location $(n=146$, one soil sample missing plus three polymerase chain reaction data records missing); $\chi^{2}=111, P<0.0001$.

${ }^{\mathrm{z}}$ Scale of 0 to 6 based on percent tuber surface area coverage, where $0=$ no disease, $1=$ trace to $5 \%, 2=6$ to $15 \%, 3=16$ to $25 \%, 4=26$ to $35 \%, 5=36$ to $60 \%$, and $6=61$ to $100 \%$.

TABLE 4. Spearman correlations of soil properties and scab severity for Ontario soils ${ }^{\mathrm{v}}$

\begin{tabular}{lcccccccc}
\hline & $\begin{array}{c}\text { Scab } \\
\text { index }^{\mathrm{w}}\end{array}$ & $\mathrm{OM}$ & $\mathrm{pH}$ & $\mathrm{CEC}$ & $\mathrm{Mn}$ & $\% \mathrm{~K}^{\mathrm{x}}$ & $\% \mathrm{Ca}^{\mathrm{x}}$ & $\% \mathrm{Mg}^{\mathrm{x}}$ \\
\hline $\begin{array}{c}2002^{\mathrm{y}} \\
\text { Scab index }\end{array}$ & 1 & 0.14 & -0.08 & 0.05 & -0.04 & 0.05 & -0.05 & 0.02 \\
$2004^{\mathrm{z}}$ & & & & & & & & \\
Scab index & 1 & $\underline{0.38}$ & -0.10 & -0.10 & $\underline{-0.38}$ & $\underline{0.45}$ & 0.10 & -0.01 \\
$\mathrm{OM}$ & $\ldots$ & 1 & -0.28 & 0.34 & -0.27 & 0.04 & -0.23 & 0.21 \\
$\mathrm{pH}$ & $\ldots$ & $\ldots$ & 1 & $\underline{0.46}$ & $\underline{0.56}$ & -0.17 & $\underline{0.65}$ & 0.23 \\
$\mathrm{CEC}$ & $\ldots$ & $\ldots$ & $\ldots$ & $\ldots$ & 0.36 & -0.35 & 0.26 & 0.13 \\
$\mathrm{Mn}$ & $\ldots$ & $\ldots$ & $\ldots$ & $\ldots$ & 1 & 0.33 & $\underline{0.38}$ & 0.08 \\
$\% \mathrm{~K}$ & $\ldots$ & $\ldots$ & $\ldots$ & $\ldots$ & $\ldots$ & 1 & 0.00 & 0.00 \\
$\% \mathrm{Ca}$ & $\ldots$ & $\ldots$ & $\ldots$ & $\ldots$ & $\ldots$ & $\ldots$ & 1 & -0.33 \\
$\% \mathrm{Mg}$ & $\ldots$ & $\ldots$ & $\ldots$ & $\ldots$ & $\ldots$ & $\ldots$ & $\ldots$ & 1 \\
\hline
\end{tabular}

${ }^{v}$ Correlations $>0.36(P<0.01)$ are underlined. Variables that were not significantly correlated for each site in 2004 are not shown. $\mathrm{OM}=$ organic matter and $\mathrm{CEC}=$ cation exchange capacity.

${ }^{\text {w }}$ Scale of 0 of 6 based on percent tuber surface area coverage, where $0=$ no disease, $1=$ trace to $5 \%, 2=6$ to $15 \%, 3=16$ to $25 \%, 4=26$ to $35 \%, 5=36$ to $60 \%$, and $6=61$ to $100 \%$.

${ }^{x}$ Because exchangeable ions are highly correlated with the respective percent base saturation, only the base saturations are shown here for brevity.

y Soil from 69 fields. Five samples were collected per field adjacent to the plants and pooled into one sample $(n=69)$.

${ }^{z}$ Soil from 14 fields and five locations (fields 6,13, and 14) or three locations (all the rest of the fields) per field. Data from the five geocaulosphere soil samples per location were averaged for this comparison $(n=48)$. 
components. The $\mathrm{Ca}$ and $\mathrm{pH}$ variables were clustered together in the same quadrant as Ontario soils and Al was negatively correlated with these variables. These results also support the bivariate results found in Table 5. In ordination plots from the two locations, the variables $\mathrm{K}: \mathrm{Mg}, \mathrm{P}$, and $\mathrm{K}$ are correlated, but have relationships to the other variables in PEI soils different from those in Ontario soils (Fig. 1A and B). A major difference between the soil samples was the relationship of CEC to the other variables.

Relationship between soil chemistry, pathogen presence, and disease. The distribution of the presence or absence of pathogenic S. scabies inoculum as identified by PCR using the $T x t A$ primer related to mean scab index in each field of the study shows that detection of TxtA alone was not consistently associated with scab severity across soil types (Table 7). The results of analysis relating soil chemical properties to low and high levels of disease based on the presence or absence of the TxtA primer are shown in Table 8 for Ontario and PEI soils. For both soils, a disease rating of $\leq 1$ or $>1$ was used as the threshold for comparison. In Ontario soils, the vast majority of samples were TxtA positive and had a scab index of $<1(n=161)$, whereas those with low disease and no detectable pathogen or high disease with detectable pathogen represented approximately one-third of the total samples ( $n=31$ and 40 , respectively) (Table 8). Thus, detection of TxtA was not a very good indicator of disease severity in these soils. In contrast, TxtA presence was better associated with disease severity in PEI soils where samples that had no detectable $T x t A$ had an average scab index of 0.1 , and those with TxtA had disease ratings of 1.2 or 3.4 (Table 8). The PCR analysis used here was unable to differentiate the quantity of bacteria present in a soil.

Comparison of Ontario samples having low disease and either a positive or negative $T x t A$ reaction with those which were $T x t A$ positive with high disease also showed that the $\mathrm{K}: \mathrm{Mg}$ variable (Table 8) was significantly related to disease, which was not demonstrated by previous analysis (Table 6). Those soils with the pathogen and high disease severity had higher $\mathrm{OM}, \mathrm{K}, \% \mathrm{~K}$, and $\mathrm{K}: \mathrm{Mg}$ ratio and lower Mn levels (Table 8).

In PEI soils, using the presence or absence data of TxtA to relate chemical factors affecting scab severity provided results almost identical (Table 8) to those found with the correlations using disease severity index as a main factor (Table 6). Those soils with the pathogen and high disease had higher $\mathrm{pH}, \mathrm{K}, \mathrm{Mg}$, $\mathrm{Ca}, \% \mathrm{~K}, \% \mathrm{Mg}, \% \mathrm{Ca}, \% \mathrm{Na}$, and $\mathrm{Cu}$ and lower $\mathrm{CEC}$ and $\mathrm{Al}$ levels (Table 8). Overall, the analysis using TxtA provided results for both soils similar to those shown for the means of the variables calculated with respect to scab index (Table 6).

Results of PCA relationships for the Ontario and PEI soils in relation to scab index and presence of pathogenic S. scabies inoculum as identified by PCR using the $T x t A$ primer are shown in Figure 2. For both soils, a disease rating of $\leq 1$ or $>1$ was used as the threshold for comparisons. There was no distinct pattern or clusters of fields found in the ordination plots relating chemical composition and TxtA presence and degree of disease severity in tubers from the Ontario soils (Fig. 2A). This may be related to the low levels of disease prevalence encountered. The clusters that were obtained reflect the properties of individual fields rather than any specific relationship among fields (Fig. 2A). However, when a ranked correlation analysis was carried out using only the samples that were $T x t A$ negative with low disease severity and TxtA positive with high disease severity, positive relationships emerged with variables $\mathrm{OM}, \mathrm{K}: \mathrm{Mg}$, and $\% \mathrm{~K}$ and negative relationships with $\mathrm{Mn}$ and $\% \mathrm{Mg}$ (Table 9). The relationship of $\mathrm{K}: \mathrm{Mg}$ and $\% \mathrm{Mg}$ were not evident previously when the whole sample was analyzed (Table 4).

For PEI soils, PCA revealed four major clusters with the clear indication that inoculum was related to high disease severity in the field (Fig. 2B). Soils in cluster one (fields 1 and 6) had no detectable PCR signal and also few diseased tubers. Soils in

TABLE 6. Comparison of mean soil properties with respect to scab severity for Ontario and Prince Edward Island geocaulosphere soil samples ${ }^{\mathrm{x}}$

\begin{tabular}{lccccc}
\hline & \multicolumn{2}{c}{ Ontario $^{y}$} & & \multicolumn{2}{c}{ Prince Edward Island } \\
\cline { 2 - 3 } \cline { 5 - 6 } Variable & $\begin{array}{c}\text { Scab index } \leq 1 \\
(n=38)\end{array}$ & $\begin{array}{c}\text { Scab index }>1 \\
(n=10)\end{array}$ & & $\begin{array}{c}\text { Scab index } \leq 1 \\
(n=13)\end{array}$ & $\begin{array}{c}\text { Scab index }>1 \\
(n=17)\end{array}$ \\
\hline $\mathrm{pH}$ & 7.3 & 7.3 & & 5.2 & $6.0^{* * * *}$ \\
$\mathrm{CEC}$ & 13 & 13 & & 10 & $7.9^{* * * *}$ \\
$\mathrm{~K}$ & 290 & $370^{* *}$ & & 180 & $240^{* * *}$ \\
$\mathrm{Ca}$ & 1,800 & 1,900 & & 440 & $720^{* * * *}$ \\
$\% \mathrm{~K}$ & 5.9 & $7.6^{* *}$ & & 4.7 & $8.1^{* * *}$ \\
$\% \mathrm{Mg}$ & 18 & 16 & & 4.6 & $7.7^{* * * *}$ \\
$\% \mathrm{Ca}$ & 68.7 & 73 & & 22 & $46^{* * * *}$ \\
$\% \mathrm{Na}$ & 0.4 & 0.4 & & 0.44 & $0.7^{* * *}$ \\
$\mathrm{Mn}$ & 67 & $49^{* *}$ & & 26 & 30 \\
$\mathrm{Cu}$ & 2.3 & $1.9^{* *}$ & & 1.1 & $2.1^{* * *}$ \\
$\mathrm{Al}$ & 1,100 & 1,100 & & 1,700 & $1,400^{* * *}$ \\
\hline
\end{tabular}

${ }^{x}$ Scale of 0 to 6 based on percent tuber surface area coverage, where $0=$ no disease, $1=$ trace to $5 \%, 2=6$ to $15 \%, 3=16$ to $25 \%, 4=26$ to $35 \%, 5=36$ to $60 \%$, and $6=61$ to $100 \%$. CEC $=$ cation exchange capacity. Significance of difference between ranked medians within each site according to the Wilcoxon ranked sum test is shown: $* *=P<0.05$, *** $=P<0.01$, or $* * * *=P<0.005$. Variables that were not significantly different in either site are not shown.

y Soil from 14 fields in 2004 and five locations (fields 6, 13, 14) or three locations (all the rest of the fields) per field. Data from the five geocaulosphere soil samples per location were averaged for this comparison $(n=48)$.

${ }^{z}$ Soil from 10 fields in 2004 and three locations per field. Data from the five geocaulosphere soil samples per location were averaged for this comparison $(n=30)$.

TABLE 5. Spearman correlations of soil properties and scab severity for Prince Edward Island soils ${ }^{\mathrm{x}}$

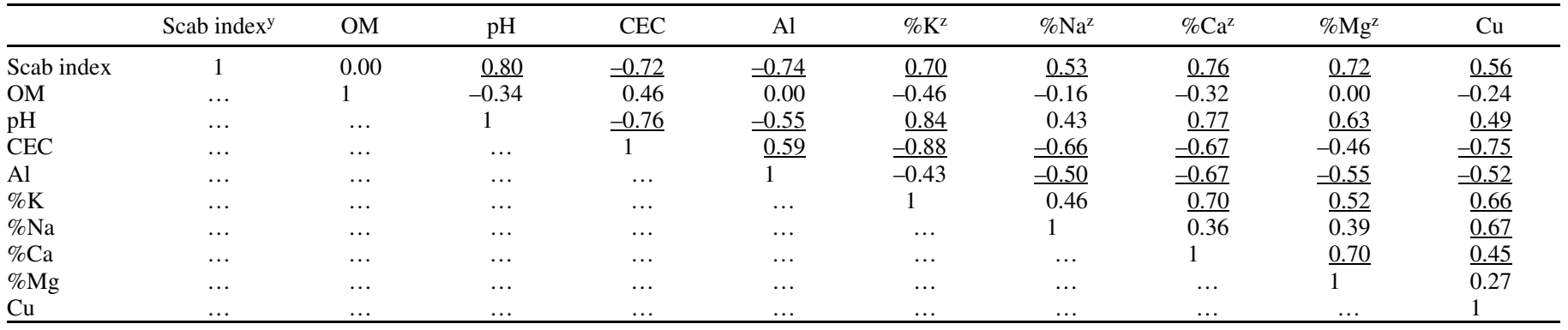

${ }^{\mathrm{x}}$ Correlations $>0.46(P<0.01)$ are underlined. Variables that were not significantly correlated for each site are not shown. Soil from 10 fields in 2004 and three locations per field. Data from the five geocaulosphere soil samples per location were averaged for this comparison $(n=30)$. OM $=$ organic matter and CEC $=$ cation exchange capacity.

${ }^{y}$ Scale of 0 to 6 based on percent tuber surface area coverage, where $0=$ no disease, $1=$ trace to $5 \%, 2=6$ to $15 \%, 3=16$ to $25 \%, 4=26$ to $35 \%, 5=36$ to $60 \%$, and $6=61$ to $100 \%$.

${ }^{\mathrm{z}}$ Because exchangeable ions are highly correlated with the respective percent base saturation, only the base saturations are shown here for brevity. 
cluster two, comprising only field 5, had positive PCR reactions but both low and high disease incidences (Fig. 2B). Cluster three (fields 3, 4, 9, and 10) represented soils with a mixture of PCR reactivity and tubers with lower to higher levels of scab coverage (Fig. 2B). In cluster four, the soil samples from all three locations (fields 2, 7, and 8) were positive for pathogenic S. scabies and the mean coverage of scab exceeded $5 \%$ (Fig. 2B).

The median scab index, percentage of samples with positive PCR, and soil components are shown in Table 10 for the four clusters identified in Figure $2 \mathrm{~B}$ for the PEI soils. The scab severity index for soils in cluster one was 0 , whereas it was 2.2 for clusters two and three and 4.5 for cluster four. PCR-positive samples were detected in $17 \%$ of the samples in cluster one, but 81 to $100 \%$ of the samples were PCR positive in clusters two to four (Table 10). The median $\mathrm{pH}$ increased progressively from 4.9 in cluster one to 6.2 in cluster four. In contrast, CEC values declined from 10 and 12 in clusters one and two, respectively, to
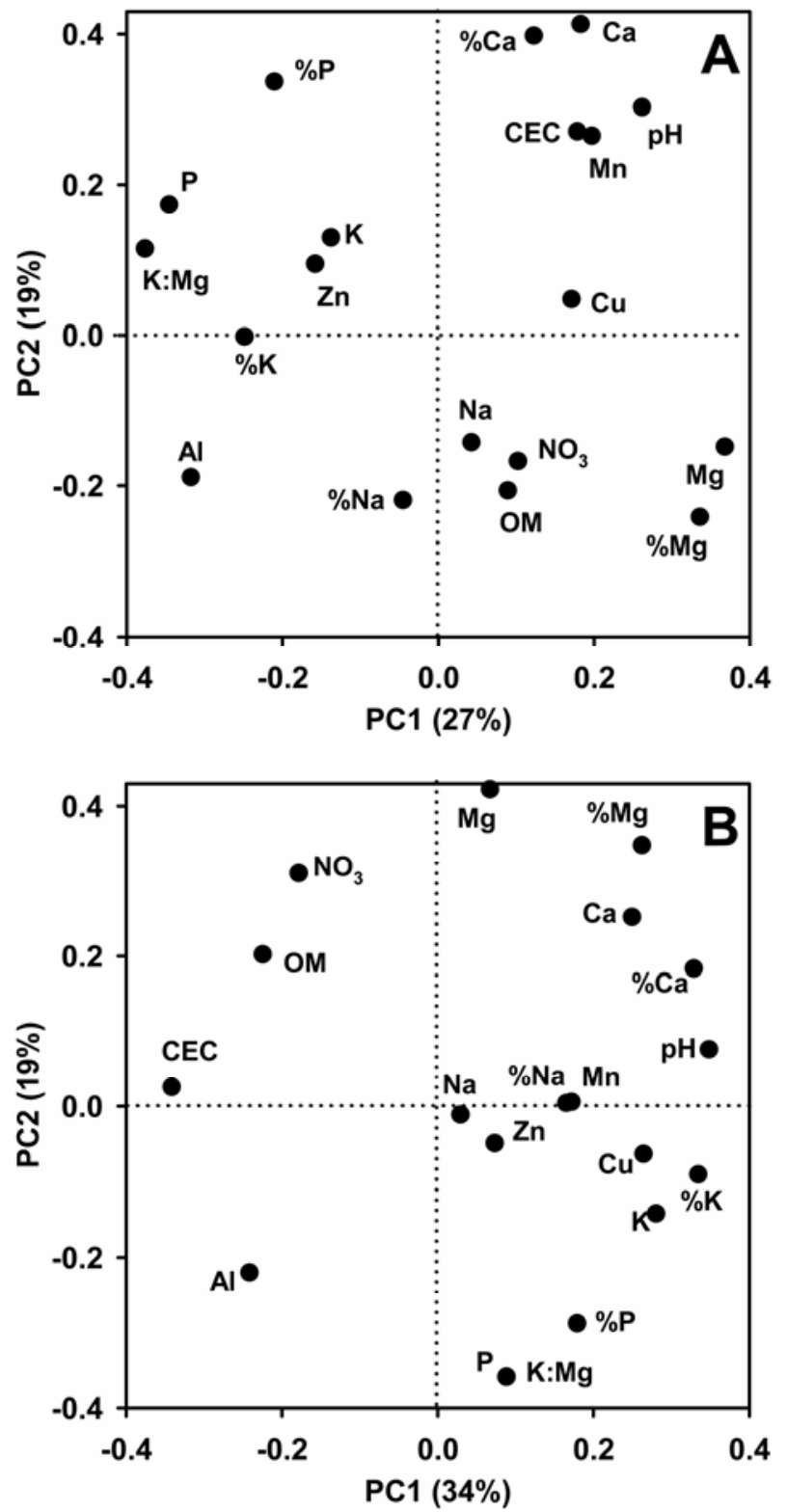

Fig. 1. Principal component (PC) loadings of soil properties from A, Ontario and $\mathbf{B}$, Prince Edward Island (PEI) soils showing soil chemistry relationships. Soils were collected in 2004. For Ontario, $n=236$; soil from 14 fields, five locations (fields 6, 13, and 14) or three locations (all the rest of the fields) per field, and five geocaulosphere soil samples per location (four soil samples missing). For PEI, $n=149$; soil from 10 fields, three locations per field, and five geocaulosphere soil samples per location (one soil sample missing).
8.1 and 6.7 in clusters three and four, respectively, as disease levels increased (Table 10). The chemical components that increased most from the soils with the lowest disease (cluster one) to that with the highest disease levels (cluster four) were $\% \mathrm{~K}$, $\% \mathrm{Na}, \% \mathrm{Mg}, \% \mathrm{Ca}$, and $\mathrm{K}$. There also was a significant decline from cluster one to four in levels of $\mathrm{NO}_{3}$ and $\mathrm{Al}$. Variables such as $\mathrm{P}$ and $\mathrm{K}: \mathrm{Mg}$, although found to be significantly correlated to various clusters, could not be clearly related to disease severity but were more specific to factors occurring in individual clusters (Table 10). Soils belonging to cluster four represented the highest median levels of $\mathrm{pH}, \% \mathrm{~K}, \% \mathrm{Ca}$, and $\% \mathrm{Mg}$ and corresponded to the locations of these variables in the variable loading plot (Fig. 1B). These soils also had the lowest levels of median CEC and Al which were negatively correlated with $\mathrm{pH}, \mathrm{Ca}, \mathrm{Mg}$, and $\mathrm{Mn}$ in the first component. Most soils with lower disease pressure in PEI samples had negative scores for both principal components and, if disease did develop on the tubers in the sample, then disease was low at $<5 \%$ average coverage. All of the samples from field 5 were positive for the TxtA sequence, but half developed more severe disease while the other half of the samples had less severe disease. The only differences in trend among field 5 samples with respect to fields with no scab (cluster one) were higher $\mathrm{pH}, \% \mathrm{Mg}$, and \% $\mathrm{Ca}$ and lower $\mathrm{K}: \mathrm{Mg}$ ratio (Table 10).

Soil chemistry models to predict scab severity. We analyzed the data with PLS regression (9) to resolve which soil-specific variables are redundant in the relationship between soil properties and disease once more influential variables have explained the variability in the occurrence of scab. An analysis with the Ontario data showed a low correlation of predicted and measured scab index (data not shown). In contrast, analysis that included all measured variables (Table 2) in PEI soils as putative predictors of scab provided several models that predicted scab with similar performance $\left(R^{2}=0.80\right.$ to 0.88$)$ (Table 11$)$. Martens' Uncertainty test (30) designated CEC, pH, OM, Ca, Al, Mn, $\mathrm{Zn}, \% \mathrm{~K}, \mathrm{Mg}$, and $\mathrm{Ca}$ as significantly predicting scab index using three components as optimum for the full model. These variables, when modeled alone (model 1), were significant predictors $\left(R^{2}=0.84\right)$ of scab severity using only two components as optimum (Table 11). Exchangeable $\mathrm{Ca}$ was omitted in further modeling, because the col-

TABLE 7. Frequency of TxtA reactivity and mean scab index in the geocaulosphere soil samples from different fields in this study

\begin{tabular}{|c|c|c|c|c|c|c|c|}
\hline \multirow[b]{4}{*}{ Field } & \multicolumn{2}{|c|}{ Ontario $^{\mathrm{x}}$} & & \multicolumn{4}{|c|}{ Prince Edward Islandy } \\
\hline & \multicolumn{2}{|c|}{ No. of samples } & \multirow[b]{3}{*}{ Index $^{\mathrm{z}}$} & \multicolumn{3}{|c|}{ No. of samples } & \multirow[b]{3}{*}{ Index $^{\mathrm{Z}}$} \\
\hline & \multicolumn{2}{|c|}{$T x t A$ reactivity } & & \multirow[b]{2}{*}{ Field } & \multicolumn{2}{|c|}{$T x t A$ reactivity } & \\
\hline & + & - & & & + & - & \\
\hline A1 & 14 & 1 & 0.4 & $\mathrm{P} 1$ & 4 & 10 & 0.4 \\
\hline A2 & 15 & 0 & 0.6 & $\mathrm{P} 2$ & 15 & 0 & 4.0 \\
\hline A3 & 10 & 5 & 0.2 & P3 & 14 & 0 & 3.2 \\
\hline A4 & 12 & 3 & 0.1 & $\mathrm{P} 4$ & 2 & 11 & 0.1 \\
\hline A5 & 14 & 0 & 0.1 & P5 & 15 & 0 & 2.2 \\
\hline A6 & 11 & 13 & 0.6 & P6 & 1 & 14 & 0.1 \\
\hline A7 & 14 & 0 & 0.0 & P7 & 15 & 0 & 3.6 \\
\hline A8 & 15 & 0 & 0.2 & P8 & 15 & 0 & 4.7 \\
\hline A9 & 15 & 0 & 0.1 & P9 & 15 & 0 & 3.0 \\
\hline A10 & 7 & 8 & 0.4 & $\mathrm{P} 10$ & 15 & 0 & 2.6 \\
\hline A11 & 11 & 4 & 0.4 & & & & \\
\hline A12 & 14 & 1 & 0.6 & & & & \\
\hline A13 & 24 & 0 & 1.6 & & & & \\
\hline A14 & 25 & 0 & 2.3 & & & & \\
\hline \multicolumn{8}{|c|}{$\begin{array}{l}\text { x Soil from } 14 \text { fields in } 2004 \text {, five locations (fields } 6,13 \text {, and } 14 \text { ) or three } \\
\text { locations (all the rest of the fields) per field, and five geocaulosphere soil } \\
\text { samples per location ( } n=236 \text {, four soil samples missing). }\end{array}$} \\
\hline \multicolumn{8}{|c|}{$\begin{array}{l}\text { y Soil from } 10 \text { fields in } 2004 \text { and three locations per field and five } \\
\text { geocaulosphere soil samples per location }(n=146 \text {, one soil sample missing } \\
\text { plus three polymerase chain reaction data records missing). }\end{array}$} \\
\hline \multicolumn{8}{|c|}{$\begin{array}{l}\text { z Scab index, scale of } 0 \text { to } 6 \text { based on percent tuber surface area coverage } \\
\text { where } 0=\text { no disease, } 1=\text { trace to } 5 \%, 2=6 \text { to } 15 \%, 3=16 \text { to } 25 \%, 4=26\end{array}$} \\
\hline
\end{tabular}


linear percent saturation of $\mathrm{Ca}$ also was included and contributed more variance in the first component than did exchangeable $\mathrm{Ca}$ (data not shown). Another model was examined which included variables from model 1 with further application of the Martens' Uncertainty test. This resulted in the more parsimonious model 2 which excluded $\mathrm{Mn}$ and $\mathrm{Zn}$ but explained $\mathrm{Y}$ variance similarly to model 1. A third model (model 3) substituted Mn for Al, but this showed little change from model $2\left(R^{2}=0.80\right)$ (Table 11). The ordination plot of individual sample scores from model 2 (Fig. 3) appears to be the most useful for the PEI region. The PLS ordination plot of variable loadings for model 2 is shown in Figure 4. High levels of $\% \mathrm{Mg}, \% \mathrm{Ca}, \mathrm{pH}$, and $\% \mathrm{~K}$ in these soils are predictive of disease severity along with low levels of CEC, OM, and Al. Indeed, comparing the score plot (Fig. 3) with the x- and yloadings plot (Fig. 4) for PEI fields with high disease severity showed higher levels of $\% \mathrm{Mg}, \% \mathrm{Ca}, \mathrm{pH}$, and $\% \mathrm{~K}$ and lower levels of CEC and Al. Interestingly, field P5, which clusters by itself, may be selected out because of its high OM level (4.1) compared with the other sites (2.6 versus 3.1) (Table 10; Figs. 3 and 4).

The variance of the best model (model 2) was high, with an RMSEC of 0.81 (Table 11), considering that the upper range of the scab index was only 6 . The plot of the predicted scab indices against the measured scab indices obtained from the calibration model showed a good correlation (0.90), but there was some scatter of the points about the correlation line (Fig. 5). The explained Y variance was good (0.80) but the inclusion of other soil properties that were not measured for this study is required to explain more of the disease variance in this sample. The cross

TABLE 8. Relationship of soil chemical components to the presence of TxtA and scab severity in Ontario and Prince Edward Island soils

\begin{tabular}{|c|c|c|c|}
\hline \multirow[b]{2}{*}{ Variable $^{\mathrm{w}}$} & \multicolumn{3}{|c|}{ Scab severity and $T x t A$ reaction ${ }^{\mathrm{x}}$} \\
\hline & $\begin{array}{c}\text { Scab index } \leq 1 \\
\text { Txt } A-\end{array}$ & $\begin{array}{c}\text { Scab index } \leq 1 \\
\text { Txt } A+\end{array}$ & $\begin{array}{c}\text { Scab index }>1 \\
\text { Txt } A+\end{array}$ \\
\hline \multicolumn{4}{|l|}{ Ontario $^{y}$} \\
\hline Scab index**** & $0.24 \mathrm{a}$ & $0.27 \mathrm{a}$ & $2.4 \mathrm{~b}$ \\
\hline $\mathrm{OM}^{* * * * *}$ & $3.6 \mathrm{a}$ & $3.9 \mathrm{a}$ & $4.6 \mathrm{~b}$ \\
\hline $\mathrm{K}^{* * * *}$ & $280 \mathrm{a}$ & $290 \mathrm{a}$ & $390 \mathrm{~b}$ \\
\hline$\% \mathrm{~K}^{* * * *}$ & $6.4 \mathrm{a}$ & $5.8 \mathrm{a}$ & $7.8 \mathrm{~b}$ \\
\hline $\mathrm{Mn} * * * *$ & $63 \mathrm{a}$ & $68 \mathrm{a}$ & $43 \mathrm{~b}$ \\
\hline $\mathrm{K}: \mathrm{Mg}^{* * *}$ & $\begin{array}{c}0.4 \mathrm{a} \\
(n=31)\end{array}$ & $\begin{array}{c}0.4 \mathrm{a} \\
(n=161)\end{array}$ & $\begin{array}{c}0.6 \mathrm{~b} \\
(n=40)\end{array}$ \\
\hline \multicolumn{4}{|c|}{ Prince Edward Island ${ }^{\mathrm{z}}$} \\
\hline Scab index**** & $0.1 \mathrm{a}$ & $0.5 \mathrm{a}$ & $3.4 \mathrm{~b}$ \\
\hline $\mathrm{CEC}^{* * * *}$ & $10 \mathrm{a}$ & $9.5 \mathrm{a}$ & $7.9 \mathrm{~b}$ \\
\hline $\mathrm{pH}^{* * * *}$ & $5.2 \mathrm{a}$ & $5.5 \mathrm{a}$ & $6.1 \mathrm{~b}$ \\
\hline $\mathrm{K}^{* * * *}$ & $180 \mathrm{a}$ & $180 \mathrm{a}$ & $240 \mathrm{~b}$ \\
\hline $\mathrm{Mg} * * * *$ & $51 \mathrm{a}$ & $62 \mathrm{a}$ & $74 \mathrm{~b}$ \\
\hline $\mathrm{Ca}^{* * * * *}$ & $430 \mathrm{a}$ & $500 \mathrm{a}$ & $720 \mathrm{~b}$ \\
\hline$\% \mathrm{~K}^{* * * *}$ & $4.7 \mathrm{a}$ & $4.9 \mathrm{a}$ & $8.2 \mathrm{~b}$ \\
\hline$\% \mathrm{Mg} * * * *$ & $4.2 \mathrm{a}$ & $5.6 \mathrm{a}$ & $7.9 \mathrm{~b}$ \\
\hline$\%$ Сa**** & $22 \mathrm{a}$ & $27 \mathrm{a}$ & $47 \mathrm{~b}$ \\
\hline$\% \mathrm{Na} * * * *$ & $0.4 \mathrm{a}$ & $0.4 \mathrm{a}$ & $0.7 \mathrm{~b}$ \\
\hline $\mathrm{Cu}^{* * * * *}$ & $1.2 \mathrm{a}$ & $1.0 \mathrm{a}$ & $2.1 \mathrm{~b}$ \\
\hline $\mathrm{Al} * * * *$ & $\begin{array}{l}1,700 \mathrm{a} \\
\quad(n=36)\end{array}$ & $\begin{array}{l}1,600 \mathrm{ab} \\
(n=8)\end{array}$ & $\begin{array}{l}1,400 \mathrm{~b} \\
\quad(n=102)\end{array}$ \\
\hline
\end{tabular}

${ }^{\mathrm{w}}$ Significance of difference $(* * * P<0.001$ or $* * * * P<0.0001)$ according to the Kruskal-Wallis test. $\mathrm{OM}=$ organic matter and $\mathrm{CEC}=$ cation exchange capacity. Means followed by the same letter within each row are not significantly different.

${ }^{x}$ Scale of 0 to 6 based on percent tuber surface area coverage, where $0=$ no disease, $1=$ trace to $5 \%, 2=6$ to $15 \%, 3=16$ to $25 \%, 4=26$ to $35 \%, 5=36$ to $60 \%$, and $6=61$ to $100 \%$.

y Soil from 14 fields in 2004, five locations (fields 6, 13, and 14) or three locations (all the rest of the fields) per field, and five geocaulosphere soil samples per location ( $n=232$, four soil samples missing and four samples were not included because they had a scab index $>1$ and were $T x t A-)$.

${ }^{\mathrm{z}}$ Soil from 10 fields in 2004, three locations per field, and five geocaulosphere soil samples per location $(n=146$, one soil sample missing plus three polymerase chain reaction data records missing). validation yielded an RMSEP of 0.93 , almost one whole scab index unit. One aspect of the data that may have contributed to this high variance in predicted scab index is that the mean predicted scab index of field P4 (index of 1.37) was higher than expected (compare with the measured mean scab index of 0.06).

Relationship between soil nutrient balance and scab severity. We examined whether differences in scab indices existed between soils considered to be imbalanced in selected nutrients versus those considered to be at optimum levels using the Kruskal-Wallis procedure (Table 12). Two of the soil factors
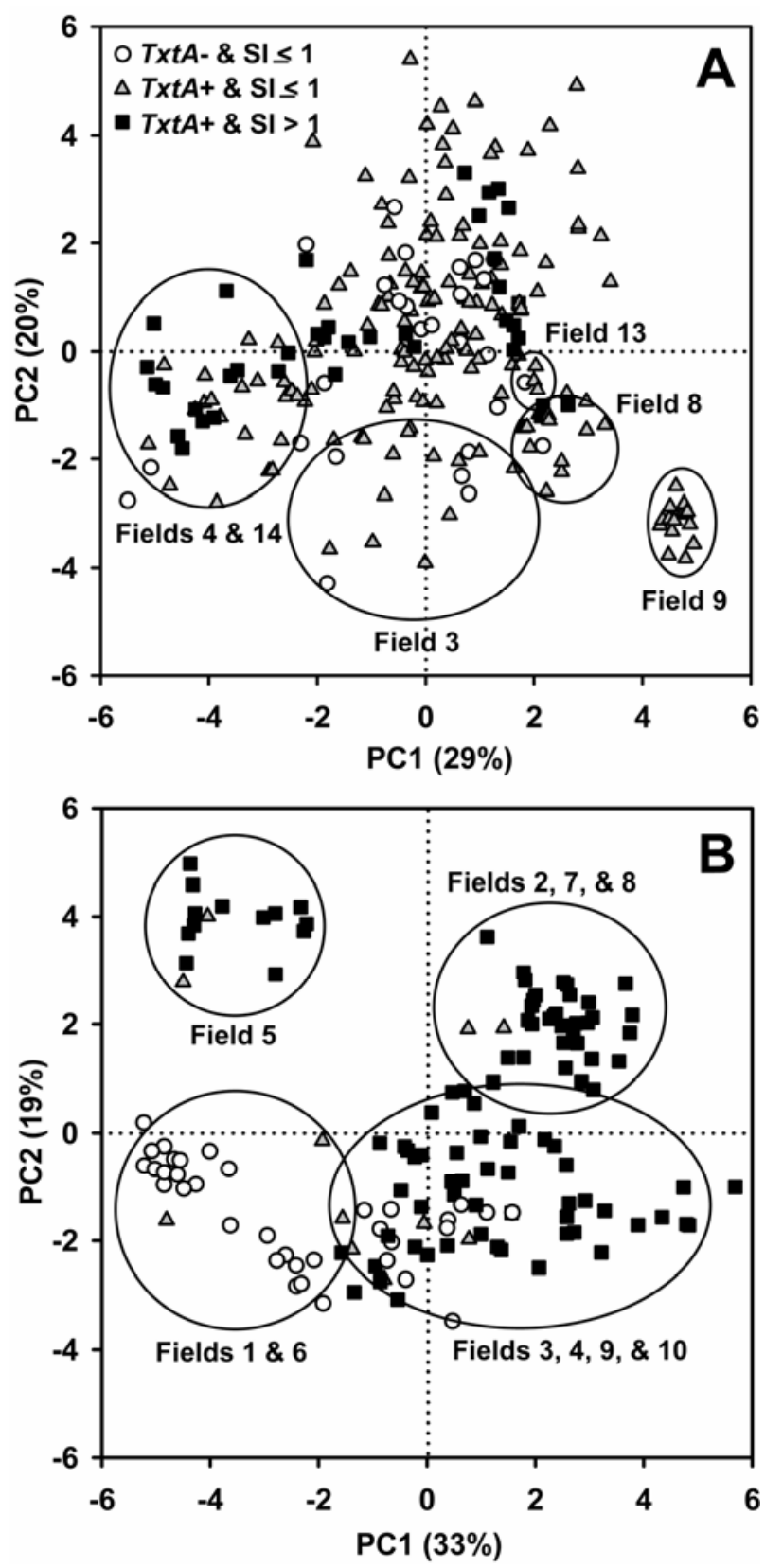

Fig. 2. Principal component (PC) scores of individual soils from A, Ontario and $\mathbf{B}$, Prince Edward Island (PEI) showing distribution of scab severity and $T x t A$ gene as identified by polymerase chain reaction. A disease rating of $\leq 1$ or $>1$ was used as the threshold rating index (SI). Disease severity was rated on a scale of 0 to 6 based on percent tuber surface area coverage, where $0=$ no disease, $1=$ trace to $5 \%, 2=6$ to $15 \%, 3=16$ to $25 \%, 4=26$ to $35 \%, 5=36$ to $60 \%$, and $6=61$ to $100 \%$. Soils were collected in 2004. For Ontario, $n=$ 236; soil from 14 fields, five locations (fields 6, 13, and 14) or three locations (all the rest of the fields) per field, and five geocaulosphere soil samples per location (four soil samples missing). For PEI, $n=149$; soil from 10 fields, three locations per field, and five geocaulosphere soil samples per location (one soil sample missing). 
TABLE 9. Spearman correlations of soil properties and scab severity for Ontario soils that were $T x t A-$ and had low disease or $T x t A+$ and had high disease ${ }^{\mathrm{x}}$

\begin{tabular}{|c|c|c|c|c|c|c|c|c|c|}
\hline & Scab index ${ }^{y}$ & $\mathrm{OM}$ & $\mathrm{pH}$ & $\mathrm{CEC}$ & $\mathrm{Mn}$ & $\mathrm{K}: \mathrm{Mg}$ & $\% \mathrm{~K}^{\mathrm{z}}$ & $\% \mathrm{Ca}^{\mathrm{z}}$ & $\% \mathrm{Mg}^{\mathrm{z}}$ \\
\hline Scab index & 1 & $\underline{0.42}$ & -0.27 & 0.03 & -0.70 & $\underline{0.52}$ & $\underline{0.49}$ & 0.01 & -0.38 \\
\hline $\mathrm{OM}$ & $\ldots$ & 1 & -0.10 & $\underline{0.49}$ & $\overline{-0.24}$ & $-\overline{0.08}$ & $-\overline{0.11}$ & 0.01 & 0.09 \\
\hline $\mathrm{pH}$ & $\ldots$ & 1.75 & 1 & 0.26 & $\underline{0.56}$ & -0.37 & -0.14 & $\underline{0.68}$ & 0.36 \\
\hline $\mathrm{CEC}$ & $\ldots$ & $\ldots$ & 1.75 & 1 & $\overline{0.28}$ & $\overline{-0.12}$ & -0.15 & $\overline{0.20}$ & 0.16 \\
\hline $\mathrm{Mn}$ & $\ldots$ & $\ldots$ & $\ldots$ & $\ldots$ & 1 & -0.61 & $\underline{-0.45}$ & 0.24 & $\underline{0.54}$ \\
\hline $\mathrm{K}: \mathrm{Mg}$ & $\ldots$ & $\ldots$ & $\ldots$ & $\ldots$ & $\ldots$ & 1 & $\underline{0.71}$ & -0.05 & $-\overline{0.84}$ \\
\hline$\% \mathrm{~K}$ & $\ldots$ & $\ldots$ & $\ldots$ & $\ldots$ & $\ldots$ & $\ldots$ & 1 & -0.10 & $\overline{-0.32}$ \\
\hline$\% \mathrm{Ca}$ & $\ldots$ & $\ldots$ & $\ldots$ & $\ldots$ & $\ldots$ & $\ldots$ & $\ldots$ & 1 & -0.12 \\
\hline$\% \mathrm{Mg}$ & $\ldots$ & $\ldots$ & $\ldots$ & $\ldots$ & $\ldots$ & $\ldots$ & $\ldots$ & $\ldots$ & 1 \\
\hline
\end{tabular}

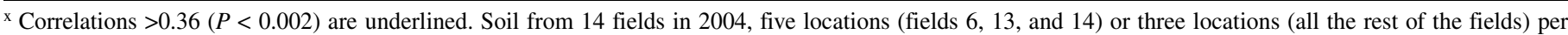
field, and five geocaulosphere soil samples per location $\left(n=236\right.$, four soil samples missing). Because $\chi^{2}$ analysis showed no association of TxtA absence or presence to disease severity, only soil samples $(n=71)$ which were either $T x t A-($ low disease severity) or $T x t A+$ and high disease severity were included. OM $=$ organic matter and $\mathrm{CEC}=$ cation exchange capacity.

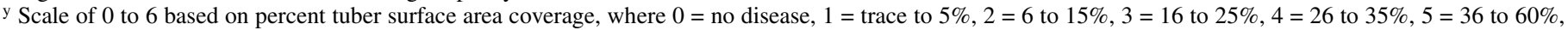
and $6=61$ to $100 \%$.

${ }^{\mathrm{z}}$ Because exchangeable ions are highly correlated with the respective percent base saturation, only the base saturations are shown here for brevity.

TABLE 10. Median values of independent variables distributed by principal component clusters arranged in order of increasing scab severity for Prince Edward Island soils ${ }^{\mathrm{y}}$

\begin{tabular}{|c|c|c|c|c|}
\hline \multirow[b]{2}{*}{ Variable $^{\mathrm{z}}$} & \multicolumn{4}{|c|}{ Cluster } \\
\hline & $\begin{array}{l}\text { One }(n=6) \\
\text { Fields } 1,6\end{array}$ & $\begin{array}{c}\text { Two }(n=3) \\
\text { Field } 5\end{array}$ & $\begin{array}{l}\text { Three }(n=12) \\
\text { Fields } 3,4,9,10\end{array}$ & $\begin{array}{l}\text { Four }(n=9) \\
\text { Fields } 2,7,8\end{array}$ \\
\hline Scab index $* *$ & 0 & 2.2 & 2.1 & 4.5 \\
\hline$\% T x t A+$ & 17 & 100 & 81 & 100 \\
\hline $\mathrm{pH} * * *$ & 4.9 & 5.4 & 5.8 & 6.2 \\
\hline CEC*** & 10 & 12 & 8.1 & 6.7 \\
\hline $\mathrm{OM}^{*}$ & 3.1 & 4.1 & 2.6 & 2.9 \\
\hline$\% \mathrm{~K}^{* * *}$ & 3.5 & 3.6 & 7.9 & 8.0 \\
\hline$\% \mathrm{Na}^{*}$ & 0.4 & 0.4 & 0.6 & 0.7 \\
\hline$\% \mathrm{Mg}^{* *}$ & 3.1 & 8.8 & 6.4 & 9.4 \\
\hline$\% \mathrm{Ca}^{* * * * *}$ & 15 & 32 & 32 & 61 \\
\hline $\mathrm{K} * * *$ & 140 & 160 & 250 & 220 \\
\hline $\mathrm{P}^{* *}$ & 120 & 66 & 210 & 100 \\
\hline $\mathrm{NO}_{3} * * * *$ & 37 & 41 & 13 & 21 \\
\hline $\mathrm{K}: \mathrm{Mg} * *$ & 1.1 & 0.4 & 1.3 & 1.0 \\
\hline $\mathrm{Al}^{* *}$ & 1,800 & 1,600 & 1,700 & 1,100 \\
\hline $\mathrm{Mn} *$ & 23 & 16 & 29 & 36 \\
\hline
\end{tabular}

y Soil from 10 fields in 2004 and three locations per field. Data from the five geocaulosphere soil samples per location were averaged for this comparison $(n=30)$.

${ }^{\mathrm{z}}$ Scale of 0 to 6 based on percent tuber surface area coverage, where $0=$ no disease, $1=$ trace to $5 \%, 2=6$ to $15 \%, 3=16$ to $25 \%, 4=26$ to $35 \%, 5=36$ to $60 \%$, and $6=61$ to $100 \%$. Significance of difference between ranked medians according to the Kruskal-Wallis test is shown: $*=P<0.05$, ** = $P<0.005, * * *=P<0.0005$, or $* * * *=P<0.0001$. CEC $=$ cation exchange capacity and $\mathrm{OM}=$ organic matter.

shown $(\mathrm{Mn}$ and $\% \mathrm{Na}$ at threshold levels of 46.5 and $0.51 \%$, respectively) were selected by the RPART recursive partitioning algorithm as the factors most discriminating between geocaulosphere samples with higher scab severity (index $>1$ ) compared with those with lower severity (index $\leq 1$ ). Levels of other soil factors were considered important by growers or consultants, or were relationships published in research articles. High $\mathrm{K}$ levels were found to be related to high scab severity in both PEI and Ontario sites. The mean scab index in soils where K exceeded $6 \%$ exchangeable ions was 1.0 for Ontario and 3.1 for PEI (Table 12). When $\mathrm{K}$ levels were $<6 \%$, the corresponding disease severities in the two soil types were 0.3 and 1.0 , respectively, or approximately one-third that found in high-K soils. Calcium levels were analyzed based on soils having $<40 \%$ exchangeable $\mathrm{Ca}, 40$ to $60 \% \mathrm{Ca}$, and $>60 \% \mathrm{Ca}$. In soils from both Ontario and PEI, there was an increasing level of scab found as \% Ca content increased (Table 12). The degree of disease increase was significant only for PEI soils having scab indices of 1.2, 3.6, and 4.4 for the three categories of $\% \mathrm{Ca}$. Soils with $\% \mathrm{Na}$ of $<0.51$ had significantly lower scab levels than those with levels above this level in both
Ontario and PEI sites (Table 12). S. scabies is a halophyte and the semiselective medium we developed incorporates salt as a selectivity factor (6). Soils with $\% \mathrm{Mg}$ levels from 10 to $20 \%$ had a significantly higher amount of scab than soil samples outside of this range in both Ontario and PEI soil samples (Table 12). Ontario soils with $\mathrm{K}: \mathrm{Mg}$ ratios $<0.2$ or $>0.4$ had higher disease levels than those between 0.2 and 0.4 (Table 12). There was no obvious relationship between scab incidence and CEC in Ontario soils; however, PEI soils with low CEC ( $<9$ meq per $100 \mathrm{~g}$ ) had higher disease severity than those with CEC levels $>9$ meq per $100 \mathrm{~g}$ (Table 12). In all, 98\% of Ontario soils had a CEC of $>9$ meq per $100 \mathrm{~g}$ soil, whereas $67 \%$ of soils from PEI were at levels $<9$ meq per $100 \mathrm{~g}$ soil. Mn levels were highly correlated with suppressing disease in Ontario soils because soils exceeding $46.5 \mathrm{ppm}$ had an average disease rating of 0.4 whereas those with levels $<46.5 \mathrm{ppm}$ had a disease rating of 1.9 (Table 12). Almost all PEI soils had $\mathrm{Mn}$ at $<46.5 \mathrm{ppm}$.

\section{DISCUSSION}

Potato growers desire control strategies for common scab that are cost effective and environmentally benign. Judicious use of fertilizers may contribute to the management of soil chemical environments such that they provide the least suitable conditions for the growth of $S$. scabies in the tuber zone and, thereby, reduce disease severity. In this study, we determined the concentrations of chemicals and the presence of bacterial pathogen, as identified by qualitative PCR assays, in soils sampled from 24 potato fields in Ontario and PEI and used bi- and multivariate statistical procedures to identify any relationships with common scab severity. We recognize that the interactions that occur at the tuber surface are highly complex and that the data collected are from a relatively few fields and at a single point in the crops' life. The results of the work presented are viewed as being the start of a comprehensive program to identify edaphic factors contributing to the increasing frequency of scab disease. Although preliminary in nature, the data reveal interesting trends as to potential interactions that can be tested further under experimental conditions. Furthermore, the methods used for data collection here, while not perfect, were an initial attempt at analyzing what is happening in the tuber zone.

Results from a survey comparing bulk soil samples and scab severity conducted in some Ontario fields in 2002 revealed very large variances in both soil chemistry and scab severity, and no correlations between soil properties and scab severity (Table 2). Subsequent studies to determine the distribution of the bacteria in soils surrounding a potato plant carried out in microplots revealed that the populations of pathogenic bacteria only increased in a significant manner in the soil surrounding the mother and 
TABLE 11. Models derived from partial least square regression of various soil properties of Prince Edward Island soils and their precision for predicting scab severity ${ }^{\mathrm{x}}$

\begin{tabular}{|c|c|c|c|c|c|c|c|}
\hline \multirow[b]{2}{*}{ Model $^{y}$} & \multicolumn{3}{|c|}{ Total variance (calibration) } & \multicolumn{4}{|c|}{ Measured versus predicted $Y$} \\
\hline & Optimum no. of components & $R^{2}$ & Explained $\mathrm{X}$ variance & RMSEC $^{\mathrm{z}}$ & Correlation coefficient & RMSEP $^{\mathrm{z}}$ & Correlation coefficient \\
\hline Full & 3 & 0.88 & 0.57 & 0.64 & 0.94 & 0.87 & 0.88 \\
\hline 1 & 2 & 0.84 & 0.61 & 0.71 & 0.92 & 0.87 & 0.88 \\
\hline 3 & 2 & 0.80 & 0.76 & 0.81 & 0.89 & 0.94 & 0.86 \\
\hline
\end{tabular}

${ }^{\mathrm{x}}$ Soil from 10 fields in 2004 and three locations per field. Data from the five geocaulosphere soil samples per location were averaged for this comparison $(n=30)$.

y Full model includes all soil variables measured and shown in Table $1(n=30)$; model 1 includes $\mathrm{CEC}, \mathrm{pH}, \mathrm{OM}, \mathrm{Ca}, \% \mathrm{Ca}, \% \mathrm{Mg}, \% \mathrm{~K}, \mathrm{Al}, \mathrm{Mn}, \% \mathrm{Na}$, and $\mathrm{Zn}$ only $(n=30)$; model 2 includes CEC, $\mathrm{pH}, \mathrm{OM}, \% \mathrm{Ca}, \% \mathrm{Mg}, \% \mathrm{~K}$, and $\mathrm{Al}$ only $(n=30)$; and model 3 includes CEC, $\mathrm{pH}, \mathrm{OM}, \% \mathrm{Ca}, \% \mathrm{Mg}, \% \mathrm{~K}$, and $\mathrm{Mn}$ only $(n=30)$.

${ }^{\mathrm{z}}$ RMSEC and RMSEP are the root mean square error for calibration data and validation data, respectively, and are directly comparable to the residual Y variance.



Fig. 3. Principal component (PC) scores after partial least squares regression of Prince Edward Island soil properties. Soil was collected from 10 fields in 2004 and three locations per field. Data from the five geocaulosphere soil samples per location were averaged for this comparison $(n=30)$.

daughter tubers (50). Thus, sampling bulk soils would not help to resolve what was happening to populations at the tuber surface. Therefore, in this study, we set out to resample fields using only soil collected from the tuber surface (geocaulosphere). Samples collected this way have relatively low variance in chemistry and disease incidence (Table 2). Analysis of these data revealed other relationships that may exist between soil chemistry and disease severity. Keinath and Loria (19) pointed out that some of the confusion in the literature relating soil chemical factors to disease likely stem from measurements taken away from the tuber zones. However, it is important to note that our data also indicate that some of the impact on disease of specific chemical constituents, such as Mn, may be soil specific.

When considering the impact of edaphic factors on plantpathogen interactions, it is risky and difficult to single out any specific component among the many factors because they all influence each other. The availability of any and all chemicals in soil is an integrated package under the influence of $\mathrm{pH}, \mathrm{OM}$, ionic exchange capacity, oxygen, moisture content, the relative concentrations of each component, and so on. This complex interaction is illustrated both in the Spearman correlations and the PCA we provided for the relationship among the various edaphic factors and chemical components for the two soils (Tables 4 and 5; Fig. 1). In both soils, certain compounds such as $\mathrm{Ca}, \mathrm{Mn}, \mathrm{pH}$, and $\mathrm{Al}$ were consistently related, but the relationships of $\mathrm{P}, \mathrm{NO}_{3}$, and $\mathrm{K}$ were different. Such soil specificity is expected given the different clay, sand, and silt contents of soils.

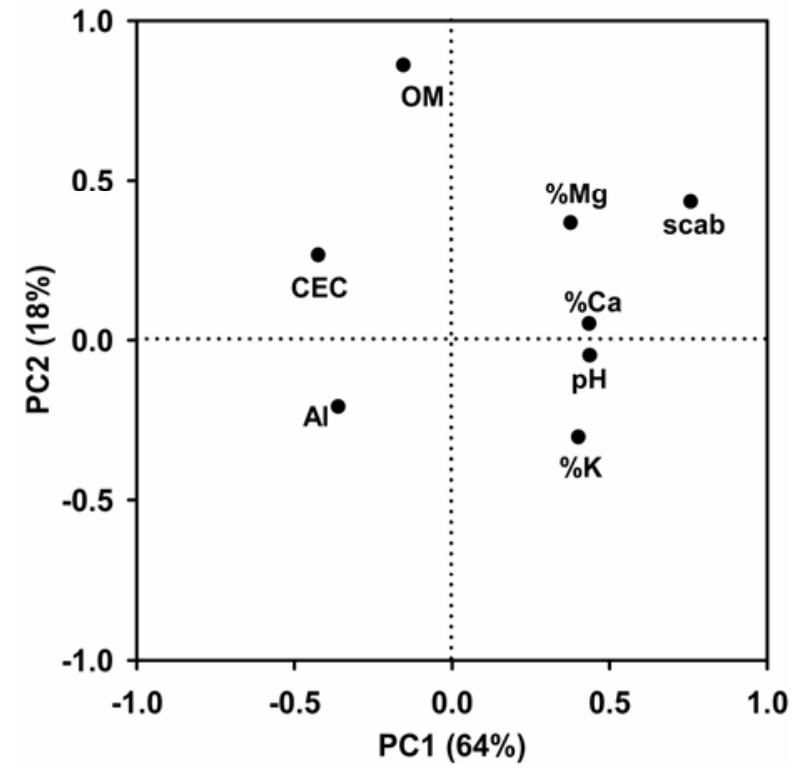

Fig. 4. Principal component (PC) loadings after partial least squares regression showing relationships of soil properties with scab severity and with each other in Prince Edward Island soils. Soil was collected from 10 fields in 2004 and three locations per field. Data from the five geocaulosphere soil samples per location were averaged for this comparison $(n=30)$.

Both Ontario and PEI soils showed a high correlation between disease severity and increasing levels of $\mathrm{K}$ and $\% \mathrm{~K}$. The levels of $\mathrm{K}$ were not related to $\mathrm{pH}$ in Ontario soils but were related to $\mathrm{pH}$ in PEI soils, indicating that $\mathrm{pH}$ was not the overriding influence here. Keinath and Loria (19) were unable to find papers associating scab severity and levels of K and Lambert et al. (22) do not mention the role of $\mathrm{K}$ at all. Potassium is the most abundant inorganic cation in plants and plays a vital role in many functions. However, its impact on plant diseases remains unclear. Huber (14) indicates that potato scab was increased as available potash or $\mathrm{Ca}$ increased. Marschner (29), however, indicates that, in general, disease resistance of plants increased with increasing $\mathrm{K}$ availability. Armengaud et al. (1) measured the transcriptional processes regulated by low $\mathrm{K}$ levels in Arabidopsis and showed that there was a significant upregulation of jasmonic acid and plant defense genes. These genes were turned off when plants were supplied with sufficient $\mathrm{K}$ for growth. They did not, however, examine what happens in the presence of high levels of $\mathrm{K}$. Research is needed to unravel how $\mathrm{K}$ may influence disease responses of plants. Based on our results, it appears that keeping $\% \mathrm{~K}$ levels to $<6 \%$ of the total base saturation may help to keep disease levels at a level where most tubers can be marketed ( $<5 \%$ coverage).

The influence of $\mathrm{pH}$ has been the most consistent factor associated with scab (22). Generally, scab is most serious in soils with $\mathrm{pH}$ ranges of 5 to 8 . In this study, we obtained a high correlation between $\mathrm{pH}$ and scab in the PEI soils, where soils with a mean $\mathrm{pH}$ value of 5.2 had low disease but those with $\mathrm{pH}$ levels of 6.0 were 
severely diseased (Table 6). In contrast, there was no relationship detected between $\mathrm{pH}$ and disease in Ontario soils where the mean $\mathrm{pH}$ value was 7.3 for soils that had higher or lower disease levels. This does not mean, however, that $\mathrm{pH}$ does not play a role in Ontario soils. We have seen that reducing the $\mathrm{pH}$ of some of these soils to $<5$ significantly lowered disease incidence (G. Lazarovits, unpublished data). However, it does suggest that, in Ontario soils, other factors may be restricting the activity of the bacteria. Several other factors may explain differences in disease severity in soils in Ontario and PEI. Because our probe does not differentiate between different species of pathogenic Streptomyces, and because $S$. acidiscabies, S. turgidiscabies, and S. scabies have quite different conditions for optimal growth, variance in disease

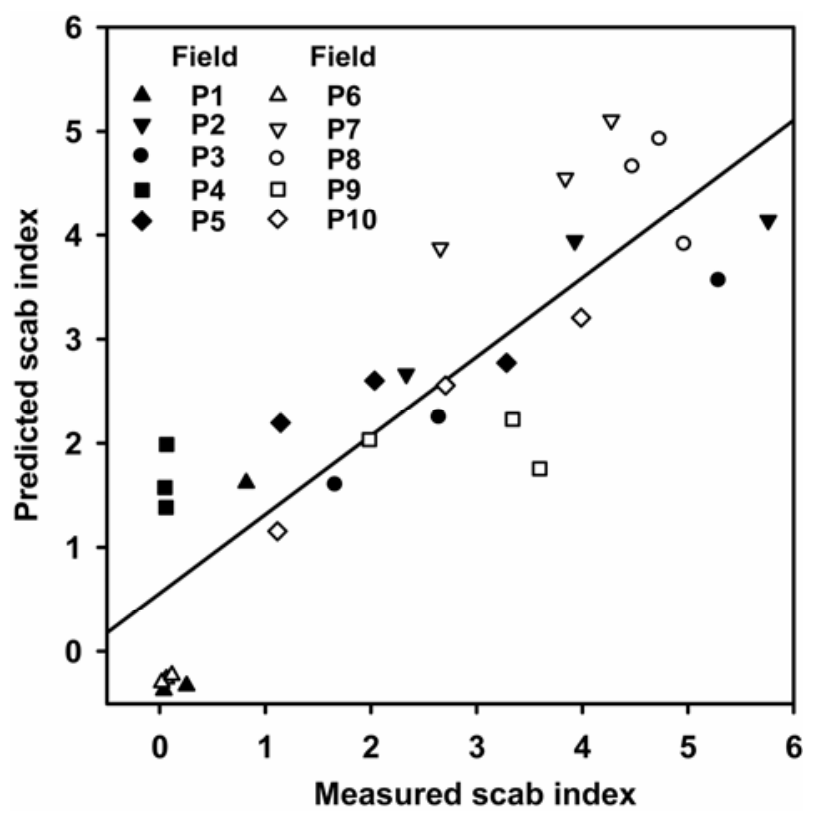

Fig. 5. Regression of predicted scab index according to partial least squares model 2 coefficients versus measured scab index and distribution of Prince Edward Island soils. Soil was collected from 10 fields in 2004 and three locations per field. Data from the five geocaulosphere soil samples per location were averaged for this comparison $(n=30)$. severity may be caused by the presence of different species in the various soils. We also did not take into consideration climatic and moisture differences among fields in the two provinces. Most Ontario growers irrigate their fields as required by the crop, whereas very few growers in PEI have irrigation equipment.

The role of $\mathrm{Ca}$ in enhancing scab disease has been extensively studied but, as yet, the specific role that $\mathrm{Ca}$ has on scab disease has not been unlinked from its effect on altering $\mathrm{pH}(19,22)$. In all statistical analyses carried out here, $\mathrm{Ca}$ and \% Ca were strongly correlated with increasing disease levels in PEI soils but were not linked to disease in Ontario soils (Table 6). The actual Ca content of Ontario soils averaged $\approx 1,800 \mathrm{ppm}$, whereas low-disease soils from PEI had a Ca content of $\approx 500$ and high-disease soils $\approx 750$, or roughly one-half the amount found in Ontario soils. In PEI soils where $\% \mathrm{Ca}$ was $<40 \%$ of the total exchangeable ions, disease severity was 1.2; however, where it was $>60 \%$, the disease rating was 4.4 , or $>50 \%$ scab coverage. The concentration of soil $\mathrm{Ca}$ does not necessarily reflect the ability of a tuber to move $\mathrm{Ca}$ into the tuber. Studies by Palta (38) and Ozgen et al. (37) have shown that $\mathrm{Ca}$ availability to plant tissues and to tubers can be vastly different as $\mathrm{Ca}$ moves with the xylem water to areas where transpiration occurs. Because tubers do not transpire much, they actually can be calcium deficient even when high levels of $\mathrm{Ca}$ are present in the soil. We did not determine the Ca levels in the tuber epidermal tissues here but will do so in future studies. Calcium plays many important roles in tuber physiology, including the regulation of stress-related factors caused by environment and disease (38). Based on the divergence of results between Ontario and PEI, Ca seems to play a site-specific role on scab disease levels.

Two factors (CEC and Mn) were highly negatively correlated with disease severity in PEI and Ontario soils, respectively. Several studies have shown that scab incidence can be lowered by application of Mn (19,22). Huber and Graham (16) indicated that Streptomyces spp. are strong Mn oxidizers and all cultural conditions which lead to increased Mn availability lead to reduced common scab, and the converse is true. However, they suggested that application of Mn to control scab would not be commercially viable because $\mathrm{Mn}$ is too quickly immobilized. The specific role that $\mathrm{Mn}$ may play in disease reduction is not known; however, in Ontario soils, levels $>57 \mathrm{ppm}$ had significantly lower disease levels than soils below this amount. Hamel et al. (12) also found

TABLE 12. Scab severity associated with selected nutrient ranges of Ontario and Prince Edward Island soils ${ }^{\mathrm{w}}$

\begin{tabular}{|c|c|c|c|c|c|}
\hline \multirow[b]{2}{*}{ Variable ${ }^{\mathrm{x}}$} & \multirow[b]{2}{*}{ Concentration range } & \multicolumn{2}{|c|}{ Ontario } & \multicolumn{2}{|c|}{ Prince Edward Island } \\
\hline & & Mean scab index $(n)^{\mathrm{y}}$ & $P$ value ${ }^{\mathrm{z}}$ & Mean scab index $(n)^{\mathrm{y}}$ & $P$ value ${ }^{z}$ \\
\hline \multirow[t]{2}{*}{$\% \mathrm{~K}$} & $>6$ & $1.0(27)$ & 0.0071 & $3.1(20)$ & 0.0049 \\
\hline & $\leq 6$ & $0.3(21)$ & $\ldots$ & $1.0(10)$ & $\ldots$ \\
\hline \multirow[t]{3}{*}{$\% \mathrm{Ca}$} & $\leq 40$ & $0(1)$ & 0.1347 & $1.2(17)$ & 0.0005 \\
\hline & $40-60$ & $0.2(4)$ & $\ldots$ & $3.6(8)$ & $\ldots$ \\
\hline & $>60$ & $0.7(43)$ & $\cdots$ & $4.4(5)$ & $\cdots$ \\
\hline \multirow[t]{2}{*}{$\% \mathrm{Na}$} & $<0.51$ & $0.5(42)$ & 0.0076 & $1.1(12)$ & 0.0046 \\
\hline & $\geq 0.51$ & $1.9(6)$ & $\ldots$ & $3.2(18)$ & $\ldots$ \\
\hline \multirow[t]{2}{*}{$\% \mathrm{Mg}$} & $<10$ or $>20$ & $0.3(20)$ & 0.1554 & $2.0(26)$ & 0.0028 \\
\hline & $10-20$ & $0.9(28)$ & $\ldots$ & $5.0(4)$ & $\ldots$ \\
\hline \multirow[t]{2}{*}{$\mathrm{K}: \mathrm{Mg}$} & $<0.2$ or $>0.4$ & $0.8(28)$ & 0.8017 & $2.4(30)$ & na \\
\hline & $0.2-0.4$ & $0.5(20)$ & $\ldots$ & $-(0)$ & $\ldots$ \\
\hline \multirow[t]{3}{*}{ CEC } & $\leq 9$ & $0.7(1)$ & 0.7243 & $3.2(20)$ & 0.0004 \\
\hline & $>9-13$ & $0.7(27)$ & $\ldots$ & $0.7(10)$ & $\ldots$ \\
\hline & $>13$ & $0.6(20)$ & $\ldots$ & $-(0)$ & $\ldots$ \\
\hline \multirow[t]{2}{*}{ Mn } & $\geq 46.5$ & $0.4(40)$ & 0.0085 & $-(0)$ & na \\
\hline & $<46.5$ & $1.9(8)$ & $\ldots$ & $2.4(30)$ & $\ldots$ \\
\hline
\end{tabular}


sphere soil samples per location were averaged for this comparison $(n=48)$. Prince Edward Island soil from 10 fields in 2004 and three locations per field. Data from the five geocaulosphere soil samples per location were averaged for this comparison $(n=30)$.

${ }^{x} \mathrm{CEC}=$ cation exchange capacity.

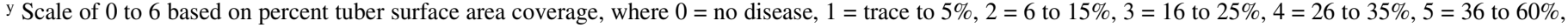
and $6=61$ to $100 \%$.

${ }^{\mathrm{z}}$ Significance of difference between medians within each variable and site according to the Wilcoxon rank sum test or Kruskal-Wallis test; na = not applicable. 
that the incidence and severity of Fusarium crown rot of asparagus was much lower in soils with high levels of Mn than in soils with lower Mn levels. However, the presence of the disease also caused a shift in the populations of microorganisms, and this shift in Mn-reducing organisms also may be involved in disease reduction (12). Interactions with disease-suppressive microorganisms may be associated with many of the chemical factors we are reporting here. How this occurs is likely to be complex. For instance, applying zinc to soils, with or without the diseasesuppressive strain of Pseudomonas aeruginosa $\mathrm{IE}-6 \mathrm{~S}^{+}$, resulted in reduced parasitic attack of tomato by root-knot nematodes and by Rhizoctonia solani (44). However, increasing $\mathrm{Zn}$ levels by themselves did not reduce infection by the root-pathogenic fungi Macrophomina solani and Fusarium solani, but the combination of $\mathrm{Zn}$ and the biocontrol bacteria resulted in marked suppression of root infections. The combination of $\mathrm{Zn}$ and the Pseudomonas spp. also resulted in lower levels of attack by the parasitic nematode (44).

PEI soils with CEC levels $<9$ meq per $100 \mathrm{~g}$ had a disease severity rating of $\approx 3.2$, whereas those $>9$ meq per $100 \mathrm{~g}$ had a rating of 0.7 (Table 12). There was no obvious relationship between CEC and disease severity observed for Ontario soils. Also, this trend in the PEI soil is opposite that reported by Lacey and Wilson (20), who found that scab was not observed in Tasmanian ferrosol soils when the combined CEC value was $\leq 12 \mathrm{cmol}_{\mathrm{C}} / \mathrm{kg}$ and $\mathrm{pH}$ levels were <4.9. Thus, relationships between some soil variables and scab are likely to be soil specific.

Overall, Ontario soil samples had much lower disease that PEI samples. A combination of factors may have led to lower scab severity among the Ontario samples compared with the PEI samples. For example, no PEI samples had levels of the $\mathrm{K}: \mathrm{Mg}$ ratio in the optimum range (0.2 to 0.4$)$ and all samples were below the Mn threshold optimum (46.5 ppm). Huber and Arny (15) suggest that the ratio of $\mathrm{K}$ to other nutrients should be considered as a factor for inducing disease severity. They indicate that the $\mathrm{K}: \mathrm{Mg}$ ratio, rather than the absolute amount of each element, is the influencing factor in increasing the disease severity for some diseases. Two-thirds of the PEI samples had CEC levels $<9$ meq per $100 \mathrm{~g}$, whereas two-thirds also had $\% \mathrm{Na}$ levels above the optimum level. We will attempt to test whether adjusting these factors can reduce scab severity in these fields.

There was an excellent association between detection of pathogenic bacteria by PCR and high disease severity in the geocaulosphere soil samples from PEI (Table 3). Ontario soils, however, had many samples that were PCR positive but whose disease levels were low. The PCR assays we used here provide only a yes or no answer but cannot be used to determine an actual quantity of inoculum, which of course is critical for calculating disease severity. Furthermore, Ontario growers often crop potato in the same soil every year, whereas PEI growers follow a 3-year rotation. Continuous potato cultivation can result in soils that are suppressive to scab disease $(25,26)$ by virtue of build-up of bacteria that are antagonistic to the scab pathogen (34). Fertilizer use also may influence microbiological diversity, as shown when higher populations of potential antagonists to scab were found when ammonium sulfate, but not ammonium nitrate, was used as a fertilizer (47).

The results from this study allow for a rudimentary modeling of relationships between soil factors and scab only for PEI soils. The model is very preliminary and has not been validated in any form. The model is known to have significant error and part of this may be due to the small sample size used in the study. Also, some error likely can be related to the use of a visual scale for rating percent lesion coverage of tubers which is not continuous but, rather, a category scale. Judging tubers with medium disease coverage is more difficult than those with little or severe disease coverage. Future studies also will need to follow more closely the changes in nutrient and bacterial concentrations in the tuber zone over the entire season. We also currently are testing the use of quantitative PCR for estimating the density of pathogens in the tuber zone because this factor alone has the major impact on disease severity and it needs to be more specifically defined. With this additional information, we hope to develop a model that can be used to predict scab incidence in fields that are imbalanced with respect to the fertility component. Some of the guidelines provided by the data in this work already may be of help for soils with properties similar to those found in PEI. However, there is considerable work required to validate our results, which we hope to do by collecting samples from many more sites. There also is a great need to examine the soil microbiology at sites where a high population of pathogen results in low disease, because suppressive conditions may be in effect at these locations.

\section{ACKNOWLEDGMENTS}

We thank W. Kelly, B. Kelly, B. Lewis, E. McMillan, and S. Squire for their help in sampling of fields; P. Martin, A. Wang, and B. Weselowski for their technical assistance; the Ontario Potato Growers Association, the Farm and Field Trials, AAFC MII, Canadapt, and Horticulture Australia Ltd. for funding of this research; and the reviewers for critical and valuable input to the manuscript.

\section{LITERATURE CITED}

1. Armengaud, P., Breitling, R., and Amtmann, A. 2004. The potassiumdependent transcriptome of Arabidopsis reveals a prominent role of jasmonic acid in nutrient signaling. Plant Physiol. 136:2556-2576.

2. Atkinson, E. J., and Therneau, T. M. 1997. An Introduction to recursive partitioning using the RPART routines. Tech. Rep. Ser. No. 61, Mayo Foundation, Rochester, MN.

3. Bronson, K. F., Booker, J. D., Keeling, J. W., Boman, R. K., Wheeler, T. A., Lascano, R. J., and Nichols, R. L. 2005. Cotton canopy reflectance at landscape scale as affected by nitrogen fertilization. Agron. J. 97:654660 .

4. Bruun, S., Stenberg, B., Breland, T. A., Gudmundsson, J., Henriksen, T. M., Jensen, L. S., Korsaeth, A., Luxhoi, J., Palmason, F., Pedersen, A., and Salo, T. 2005. Empirical predictions of plant material $\mathrm{C}$ and $\mathrm{N}$ mineralization patterns from near infrared spectroscopy, stepwise chemical digestion and C/N ratios. Soil Biol. Biochem. 37:2283-2296.

5. Conn, K. L., and Lazarovits, G. 1999. Impact of animal manures on Verticillium wilt, potato scab, and soil microbial populations. Can. J. Plant Pathol. 21:81-92.

6. Conn, K. L., Leci, E., Kritzman, G., and Lazarovits, G. 1998. A quantitative method for determining soil populations of Streptomyces and differentiating potential potato scab-inducing strains. Plant Dis. 82:631638.

7. Criquet, S., Ferre, E., Farnet, A. M., and Le Petit, J. 2004. Annual dynamics of phosphatase activities in an evergreen oak litter: influence of biotic and abiotic factors. Soil Biol. Biochem. 36:1111-1118.

8. Dewdney, M., Charest, J., Paulitz, T., and Carisse, O. 2003. Multivariate analysis of apple cultivar susceptibility to Venturia inaequalis under greenhouse conditions. Can. J. Plant Pathol. 25:387-400.

9. Esbensen, K. 2004. Multivariate Data Analysis in Practice, 5th ed. CAMO Process AS, Oslo, Norway.

10. Feng, Y., Motta, A. C., Reeves, D. W., Burmester, C. H., Van Santen, E., and Osborne, J. A. 2003. Soil microbial communities under conventionaltill and no-till continuous cotton systems. Soil Biol. Biochem. 35:16931703 .

11. Gavlak, R., Horneck, D., and Miller, R. O. 1997. Plant, soil and water reference methods for the Western region. Western States Laboratory Proficiency Testing Program, Soil and Plant Analytical Methods, version 4.00. Oregon State University, Corvallis, OR.

12. Hamel, C., Vujanovic, V., Nakano-Hylander, A., Jeannotte, R., and St.Arnaud, M. 2005. Factors associated with Fusarium crown and root rot of asparagus outbreaks in Quebec. Phytopathology 95:867-873.

13. Hill, J. L., and Lazarovits, G. 2005. A mail survey of growers to estimate potato common scab prevalence and economic loss in Canada. Can. J. Plant Pathol. 27:46-52.

14. Huber, D. M. 1991. The use of fertilizers and organic amendments in the control of plant disease. Pages 405-494 in: Handbook of Pest Management in Agriculture. D. Pimental, ed. CRC Press, Boca Raton, FL.

15. Huber, D. M., and Arny, D. C. 1985. Interactions of potassium with plant disease. Pages 467-488 in: Potassium in Agriculture. R. D. Munson, ed. American Society of Agronomy, Madison, WI. 
16. Huber, D. M., and Graham, R. D. 1999. The role of nutrition in crop resistance and tolerance to diseases. Pages 169-204 in: Mineral Nutrition of Crops: Fundamental Mechanism and Implications. Z. Rengal, ed. Food Products Press, New York.

17. Jacobsen, S., Sondergaard, I., Moller, B., Desler, T., and Munck, L. 2005. A chemometric evaluation of the underlying physical and chemical patterns that support near infrared spectroscopy of barley seeds as a tool for explorative classification of endosperm, genes and gene combinations. J. Cereal Sci. 42:281-299.

18. Jones, B. J., Jr. 1999. Soil Analysis, Handbook of Reference Methods. Soil and Plant Analysis Council Inc., Boca Raton, FL.

19. Keinath, A. P. L. R., and Loria, R. 1989. Management of common scab of potato with plant nutrients. Pages 152-166 in: Soilborne Plant Pathogens: Management of Disease with Macro- and Microelements. American Phytopathological Society, St. Paul, MN.

20. Lacey, M. J., and Wilson, C. R. 2001. Relationship of common scab incidence of potatoes grown in Tasmanian ferrosol soils with $\mathrm{pH}$, exchangeable cations and other chemical properties of those soils. J. Phytopathol. 149:679-683.

21. La Manna, L., and Rajchenberg, M. 2004. Soil properties and Austrocedrus Chilensis forest decline in central Patagonia, Argentina. Plant Soil 263:29-41.

22. Lambert, D. H., Powelson, M. L., and Stevenson, W. R. 2005. Nutritional interactions influencing diseases of potato. Am. J. Potato Res. 82:309319.

23. Lazarovits, G., Conn, K. L., and Potter, J. 1999. Reduction of potato scab, Verticillium wilt, and nematodes by soymeal and meat and bone meal in two Ontario potato fields. Can. J. Plant Pathol. 21:345-353.

24. Lazarovits, G., Tenuta, M., and Conn, K. L. 2001. Organic amendments as a disease control strategy for soilborne diseases of high-value agricultural crops. Australas. Plant Pathol. 30:111-117.

25. Liu, D., Anderson, N. A., and Kinkel, L. L. 1995. Biological control of potato scab in the field with antagonistic Streptomyces scabies. Phytopathology 85:827-831.

26. Liu, D., Anderson, N. A., and Kinkel, L. L. 1996. Selection and characterization of strains of Streptomyces suppressive to the potato scab pathogen. Can. J. Microbiol. 42:487-502.

27. Loria, R., Bukhalid, R. A., Fry, B. A., and King, R. R. 1997. Plant pathogenicity in the genus Streptomyces. Plant Dis. 81:836-846.

28. Mackenzie, M. D., Deluca, T. H., and Sala, A. 2004. Forest structure and organic horizon analysis along a fire chronosequence in the low elevation forests of western Montana. For. Ecol. Manage. 203:331-343.

29. Marschner, H. 1997. Mineral Nutrition of Higher Plants. Academic Press, Toronto.

30. Martens, H., and Martens, M. 2000. Modified jack-knife estimation of parameter uncertainty in bilinear modelling by partial least squares regression (PLSR). Food Qual. Prefer. 11:5-16.

31. Martens, H., and Naes, T. 1989. Multivariate Calibration. John Wiley and Sons, Chichester, UK.

32. McGregor, A. J., and Wilson, G. C. S. 1966. The influence of manganese on the development of potato scab. Plant Soil 25:3-16.

33. Min, M., Lee, W. S., Kim, Y. H., and Bucklin, R. A. 2006. Nondestructive detection of nitrogen in chinese cabbage leaves using VIS-NIR spectroscopy. HortScience 41:162-166.

34. Neeno-Eckwall, E. C., Kinkel, L. L., and Schottel, J. L. 2001. Competition and antibiosis in the biological control of potato scab. Can. J. Microbiol. 47:332-340.

35. Nsabimana, D., Haynes, R. J., and Wallis, F. M. 2004. Size, activity and catabolic diversity of the soil microbial biomass as affected by land use. Appl. Soil Ecol. 26:81-92.

36. Oyarzun, P. J., Gerlagh, M., and Zadoks, J. C. 1998. Factors associated with soil receptivity to some fungal root rot pathogens of peas. Appl. Soil Ecol. 10:151-169.

37. Ozgen, S., Karlsson, B., and Palta, J. P. 2006. Response of potatoes (cv. Russet Burbank) to supplemental calcium applications under field conditions: Tuber calcium, yield, and incidence of internal brown spot. Am. J. Potato Res. 83:195-204.

38. Palta, J. P. 1966. Role of calcium in plant responses to stresses: Linking basic research to the solution of practical problems. HortScience 31:5157.

39. Ping, J. L., Green, C. J., Bronson, K. F., Zartman, R. E., and Dobermann, A. 2004. Identification of relationships between cotton yield, quality, and soil properties. Agron. J. 96:1588-1597.

40. Powelson, M. L., Johnson, K. B., and Rowe, R. C. 1993. Management of diseases caused by soilborne pathogens. Pages 149-158 in: Potato Health Management. American Phytopathological Society, St. Paul, MN.

41. SAS Online Doc version 9.1.3. 2004. SAS Institute Inc., Cary, NC.

42. Selvin, S. 1995. Practical Biostatistical Methods. Duxbury Press, Belmont, CA.

43. Shiga, H., and Suzuki, K. 2004. Effect of Soil Acidity, Organic Soil Amendment and Green Manure on Potato Scab. International Potato Scab Symposium (IPSS2004), Sapporo, Japan.

44. Siddiqui, I. A., Shaukat, S. S., and Hamid, M. 2002. Role of zinc in rhizobacteria-mediated suppression of root-infecting fungi and root-knot nematode. J. Phytopathol. 150:569-575.

45. Statistics Canada. 2003. Farm Cash Receipts (potatoes). Statistics Canada, Ottawa, ON, Canada.

46. Stenberg, B. 1998. Soil attributes as predictors of crop production under standardized conditions. Biol. Fertil. Soil 27:104-112.

47. Sturz, A. V., Ryan, D. A. J., Coffin, A. D., Matheson, B. G., Arsenault, W. J., Kimpinski, J., and Christie, B. R. 2004. Stimulating disease suppression in soils: Sulphate fertilizers can increase biodiversity and antibiosis ability of root zone bacteria against Streptomyces scabies. Soil Biol. Biochem. 36:343-352.

48. Venables, W. N. 2002. Modern Applied Statistics with S. Springer-Verlag, New York.

49. Wang, A. X., and Lazarovits, G. 2004. Enumeration of plant pathogenic Streptomyces on postharvest potato tubers under storage conditions. Can. J. Plant Pathol. 26:563-572.

50. Wang, A. X., and Lazarovits, G. 2005. Role of seed tubers in the spread of plant pathogenic Streptomyces and initiating potato common scab disease. Am. J. Potato Res. 82:221-230.

51. Waterer, D. 2002. Management of common scab of potato using planting and harvest dates. Can. J. Plant Sci. 82:185-189. 